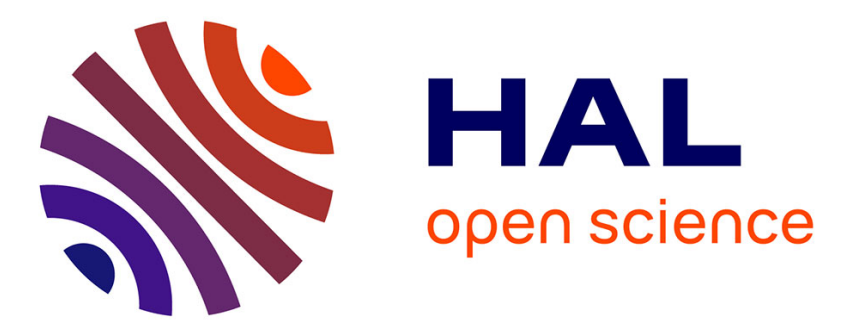

\title{
Pre-salt to salt stratigraphic architecture in a rift basin: insights from a basin-scale study of the Gulf of Suez (Egypt)
}

Sébastien Rohais, Aurélien Barrois, Bernard Colletta, Isabelle Moretti

\section{- To cite this version:}

Sébastien Rohais, Aurélien Barrois, Bernard Colletta, Isabelle Moretti. Pre-salt to salt stratigraphic architecture in a rift basin: insights from a basin-scale study of the Gulf of Suez (Egypt). Arabian Journal of Geosciences, 2016, 9 (4), 10.1007/s12517-016-2327-8 . hal-01338357

\section{HAL Id: hal-01338357 https://hal.science/hal-01338357}

Submitted on 28 Jun 2016

HAL is a multi-disciplinary open access archive for the deposit and dissemination of scientific research documents, whether they are published or not. The documents may come from teaching and research institutions in France or abroad, or from public or private research centers.
L'archive ouverte pluridisciplinaire HAL, est destinée au dépôt et à la diffusion de documents scientifiques de niveau recherche, publiés ou non, émanant des établissements d'enseignement et de recherche français ou étrangers, des laboratoires publics ou privés. 


\section{Pre-salt to salt stratigraphic architecture in a rift basin: insights from a basin-scale study of the Gulf of Suez (Egypt)}

Sébastien ROHAIS ${ }^{(1 *)}$, Aurélien BARROIS ${ }^{(2)}$, Bernard COLLETTA $^{(2)}$, Isabelle MORETTI ${ }^{(3)}$

(1) IFPEN, Direction Géosciences, 1 et 4 Avenue de Bois-Préau, 92852 Rueil-Malmaison Cedex. France

(2) Beicip-Franlab, 232, Av. Napoléon Bonaparte, 92502 Rueil-Malmaison Cedex. France

(3) ENGIE EPI, Département Exploration et Géosciences, 1 Place Samuel de Champlain, 92930 Paris La Défense Cedex

*e-mail address of corresponding author: sebastien.rohais@ifpen.fr

\section{INTRODUCTION}

Understanding the geology of extensional basins has a major economic impact as more than a third of the global hydrocarbon resources are hosted in rift basins (Mann et al. 2003). Rift basins have even faced a renewed interest during the 2000's with the increase in quality of seismic data resulting in huge discoveries from some rift systems below the salt along Brazilian and African margins (Martin et al. 2009; O’Reilly et al. 2015).

Additionally, if rifts record generally the initial stage of crustal extension they occurred in a wide diversity of tectonic settings ranging from cratonic to orogenic belts settings. Rift basins have then been studied to address many scientific challenges such as the stretching of the continental lithosphere (e.g. McKenzie 1978; Wernicke 1985; Sleekler 1986; Moretti and Chenet 1987), fault dynamics (e.g. Moretti and Colletta 1987; Colletta et al. 1988; Moustafa 1996; Gawthorpe et al. 1997; Gupta et al. 1998; Cowie et al. 2000; Jackson et al. 2002; Khalil and McClay 2002) and the tectonic, sedimentation and erosion relationship (e.g. Leeder and Gawthorpe 1987; Garfunkel 1988; Montenat et al. 1988; Gawthorpe et al. 1990; Lambiase 
and Bosworth 1995; Bosence et al. 1998; Bosworth et al. 1998; Gupta et al. 1999; Rohais et surficial extensional structures and the deeper mantle thermal state, many scientific works were addressed to understand the relationship between the subsidence, or more generally the vertical movements, and the extension during the rift phases. The initial model of McKenzie (1978) emphased the role of lithospheric and crustal thinning and especially the post-rift thermal evolution of the upper mantle to qualify the post-rift subsidence. This post-rift subsidence is slow since it is mainly a thermal readjustment and is controlled by the conductivity of the mantle. At that time, discussions were still ongoing on the possibility of having fast crustal thinning induced by deep thermal anomaly or by far field extensional stresses (active versus passive rifting debate). It has then been proven that the crustal and lithospheric thinning can be fast enough to fit with the data which show extension may happen in just a few millions of years by taking into account a realistic rheology for the mantellic and crustal rock (e.g. Fleitout and Yuen 1984). In these purely active rifting models, the crustal extension is only due to the deep thermal asthenosphere anomaly however the far field stresses, that could be or not extensive, influence the resulting rift geometry as proposed by Moretti and Froidevaux (1986). The difference between the amount of upper crustal extension (Ext $)_{c}$ and crustal thinning $\left(\beta_{c}\right)$ has also been recognized for a long time, since deep seismic profiles have been acquired. $\beta_{\mathrm{c}}$ is always bigger than Ext $\mathrm{c}_{\mathrm{c}}$ and this difference was classically interpreted by the authors, in the active rift scheme, in term of different rheologies: brittle upper crust and ductile lower crust (Moretti and Pinet, 1987). However, based also on the first deep seismic acquisitions, it has been noticed that the localization of the maximum of the crustal thinning may not correspond to the maximum of extension in the upper crust and proposed crustal-scale fault (i.e. rather brittle lower crust, Wernicke 1985). Meanwhile, data from basins where the subsidence is huge compare to the upper crustal extension suggested 
that gravity anomalies induced by phase change in the lower crust may also induce subsidence without any far field extension or mantellic thermal anomaly (Sleep et al., 1980; Artyushkov and Baer, 1984). Later the works of Huysman (1999) have proven that the "future" of any passive rift is an active one since the destabilization of the lithosphere/asthenosphere boundary is sufficient to start a mantellic convective cell that will speed up the lithospheric thinning. The common characteristic of all these proposals to explain rifting, which are not contradictory as all extensional areas have not necessarily the same origin, is that they neglect the effect of the surface processes on the rift evolution. The recognition of the coupling between erosion/sedimentation and deep processes has been facilitated for the last 15 years by the improvement of softwares used to model the lithospheric evolution. This improvement now allows us not only to compute isostatic rebound related to erosion or subsidence due to sediment load, but also to quantify how the upper crustal loading/unloading may influences the mantellic state (Burov and Poliakov, 2001; Haines et al. 2003; Cloetingh et al. 2012). One of the key objectives at present is establishing the relationship between deep and surface processes; how does subsidence / extension / uplift / erosion interact all along a rift history? A major limitation preventing the implementation and optimization of these numerical models is the lack of a well constrained case study. A better calibration of theoretical concepts to real data observations is essential to deliver applicable results. Synthetic overviews have been proposed for the evolution from rifting (e.g. Chaboureau et al. 2013; Macgregor 2015) up to oceanic spreading (e.g. Leroy et al. 2012). However, the time step and depositional system description do not provide enough resolution to constrain, at high resolution, the evolution of a full rift system from its initiation to late rift stages.

The present contribution proposes a basin-scale study of a rift basin resulting in a geological scenario including its timing, depocenter migration, depositional system evolution and erosion-sedimentation relationship. The Suez rift has been selected to address this topic as it 
provides a well constrained geological setting with high resolution dating constraints and a

large quantity of accessible and diversified data from both outcrop and subsurface. This study is focused on the pre-salt to salt series of the Suez rift that correspond to Oligo-miocene synrift deposits recording the rift initiation to the latest rift phases.

\section{SUEZ RIFT: GEOLOGIC BACKGROUND AND BASIN SETTING}

The Suez rift is the NW-SE-trending branch of the Red Sea rift system (Figure 1), resulting from the late Oligocene to early Miocene rifting of the African and Arabian plates (Garfunkel and Bartov 1977). It is bounded on both margins by large-scale normal fault zones (fault length $\sim 40-80 \mathrm{~km}$, fault throw $\sim 2-6 \mathrm{~km}$ ). The polarity of the block-bounding faults changes along the axis of the rift, dividing the rift into three $50-100 \mathrm{~km}$ long tectonic domains (Colletta et al. 1988; Patton et al. 1994; Moustafa 1996): (1) the northern Darag basin with southwest dips; (2) the Central basin (Belayim province) with northeast dips; (3) the Southern basin (Amal-Zeit province) with southwest dips (Figure 1a). In between, two major ca. 20-km wide accommodation zones exist (Colletta et al. 1988): the Zaafarana and the Morgan accommodation zones (Figure 1a).

The stratigraphic succession of the Gulf of Suez includes pre-rift and syn-rift successions (Figure 1c). The pre-rift succession is presented hereafter as it constitutes the catchment unit feeding the syn-rift depositional systems. It comprises a Precambrian Pan-African crystalline basement unconformably overlain by a 1-km thick succession of Cambrian to Eocene sedimentary rocks that progressively thins toward the south. This sedimentary succession can be subdivided into three distinct units (e.g. Moustafa 1976; Garfunkel and Bartov 1977): (1) the "Nubia Sandstones" corresponding to several formations which mostly consist of fluvial sandstones (Cambrian to Early Cretaceous), (2) a Late Cretaceous mixed carbonate- 
siliciclastic succession and (3) a Paleocene-Eocene carbonate-dominated succession (Figure $1 c)$.

The transition from pre-rift to syn-rift is locally recorded by red bed deposits overlying a major angular unconformity (Figure 1c). They correspond to the Tayiba and Abu Zenima Formations (Figure 1c) that are commonly attributed to the Oligo-Miocene. This date is based on interbedded basaltic flows and/or volcanic material found within these formations, which absolute K-Ar ages span from 21 to 27 Ma (e.g. Montenat et al. 1986; Plaziat et al. 1998). The syn-rift Miocene succession is subdivided into the Gharandal Group consisting of the Nukhul, Rudeis and Kareem Formations, and the Ras Malaab Group consisting of the Belayim, South Gharib and Zeit Formations (e.g. EGPC 1964; Figure 1c, Figure 2). The postZeit succession includes the Wardan and Zaafarana Formations (Figure 2), attributed to the Plio-Pleistocene (e.g. Abd El Shafy 1990). The post-Zeit deposits are not presented in this paper as they correspond to post-rift deposits (Figure 1c).

The Nukhul Formation is Aquitanian-Early Burdigalian in age (e.g. Garfunkel and Bartov, 1977; Fawzy and Abdel Aal 1984; Scott and Govean 1985) and is subdivided into a basal Shoab Ali Member and other three time equivalent members: the Ghara, October and Gharamul Members (Saoudi and Khalil 1984, Figure 2). The Nukhul Formation includes sabkha-type evaporites (anhydrite) and shales, marginal to shallow-marine calcareous conglomerates, reefs and platform carbonates, sandstones, marls and deep marine shales (e.g. Ghorab 1964; Hughes et al. 1992).

The Rudeis Formation is Burdigalian to Early Langhian in age (e.g. Bunter 1980; Smale et al. 1988; Hughes et al. 1992) and is generally subdivided into several members that are commonly grouped into a Lower Rudeis and an Upper Rudeis units (EGPC 1964, Figure 2). The boundary between them is defined by a sharp limit and facies change recording a basinward shift (Garfunkel and Bartov 1977). The Rudeis Formation includes widespread, 
offshore marly/shaly deposits with thin sandstone beds (Lower Rudeis) interpreted as turbidite and siltstones (Upper Rudeis) (Ghorab 1964). The Rudeis Formation also includes shallow marine reefal carbonates developed along isolated tilted block crests (Burchette 1987; Bosence et al. 1998).

The Kareem Formation is Langhian in age (e.g. Garfunkel and Bartov 1977; Allen et al. 1984) and is subdivided into a basal Markha Member (equivalent to Rahmi Member) and an upper Shagar Member (EGPC, 1964, Figure 2). The Markha Member mainly includes thin anhydrite beds interbedded with shale, marls and carbonates. The Shagar Member includes shallow marine carbonates and sandstones to deep-water marls and dark grey shales (Ghorab 1964). The Belayim Formation is Serravallian in age (e.g. Bunter 1980; Scott and Govean 1985) and includes four members: the Baba, Sidri, Feiran and Hammam Faraun Members (EGPC 1964). The Belayim Formation consists of alternating halite, anhydrites, siliciclastics and reef carbonates composed of red-algae (Nullipore limestone defined by Sellwood and Netherwood 1984) recording a wide spectrum of depositional environments from lagoonal and shallow platform to deep marine (Figure 2).

The South Gharib Formation is Serravallian to Tortonian (e.g. Bunter 1980; Scott and Govean 1985; Smale et al. 1988, Figure 2) and consists of massive halite and thin anhydrite beds interbedded with fine-grained sandstones and shales associated to an alternation of restricted hypersaline environments with moderately deep to shallow marine environments (Hughes et al. 1992; Rouchy et al., 1995).

The Zeit Formation is Messinian (e.g. Bunter 1980; Scott and Govean 1985; Zierenberg and Shanks 1986; Richardson and Arthur 1988) and consists of halite, gypsum, anhydrite beds interbedded with fine-grained sandstones, siltstones and shales associated to shallow marine 
environments that record alternating restricted to open marine conditions (Hughes et al. 1992; Rouchy et al., 1995; Orszag-Sperber et al. 1998).

\section{DATA AND METHODOLOGY}

The database used in the present study results from more than thirty years of collaborative projects leaded by the co-authors with industrial and academic partners on the Suez rift (Chenet 1984; Chenet et al. 1984; Le Quellec and Colletta 1985; Moretti and Froidevaux 1986; Moretti 1987; Moretti and Pinet, 1987; Moretti and Colletta 1987; Colletta et al. 1988; Piron 2000; Rohais et al. 2007b; Gargani et al. 2008; Barrois et al. 2010; Barrois 2011; Rohais et al. 2015). It has been uploaded with published works including sedimentological outcrop sections (Burchette 1987; Evans, 1990; Moustafa 1993; Krebs et al. 1997; Bosworth et al. 1998; Gupta et al. 1999; Winn et al. 2001; Abdelghany 2002; Gawthorpe et al. 2003; Jackson et al. 2002; Young et al. 2000; 2003), wells (Hagras and Slocki 1982; Saoudi and Khalil 1984; Chowdhary et al. 1986; Gawad et al. 1986; Hagras 1986; Helmy and Zakaria 1986; Evans 1988; Hughes et al. 1992; Schütz 1994; Halim et al. 1996; Salah and Alsharhan 1997; Bosworth et al. 1998; El Beialy and Ali 2002; Gawthorpe et al. 2003; Khaled et al. 2002; El Beialy et al. 2005; Gargani et al. 2008; Abd El-Naby et al. 2010; Omran and El Sharawy 2014), geological maps, cross-section, isopach and structural maps (Garfunkel and Bartov 1977; Hagras and Slocki 1982; Saoudi and Khalil 1984; Le Quellec and Colletta 1985; Helmy and Zakaria 1986; Colletta et al. 1988; Richardson and Arthur 1988; Schütz 1994; Patton et al. 1994; McClay et al. 1998; Bosworth and McClay 2001; Khalil and McClay 2002; Khaled et al. 2002; Peijs et al. 2012) and paleogeographic maps (Hagras and Slocki 1982; Saoudi and Khalil 1984; Richardson and Arthur 1988; Hughes et al. 1992; Schütz 1994; Salah and Alsharhan 1997; Bosworth et al. 1998; Khaled et al. 2002; Gawthorpe et al. 2003; Peijs et al. 2012). 
The workflow developed hereafter includes firstly a structural map interpretation and

synthesis based on new fieldwork and previous published works (Figure 1). Secondly, sequence stratigraphic correlation has been carried out using 279 wells and 31

sedimentological outcrop sections distributed all over the basin (Figure 1). We refer to the stratigraphic surfaces based on the published microfossils and data following the synthesis by Richardson and Arthur (1988), Hughes et al. (1992) and El Beialy et al. (2005) (Figure 2). These surfaces have been correlated all over the basin along several longitudinal and dip cross sections (Figure 3). We then calibrated these stratigraphic ages into absolute ages using the ICS (2004) stratigraphic chart based on the synthesis by Gradstein et al. (2012) (Figure 2). The pioneer work done by Hughes et al. (1992) has also been used to subdivide the stratigraphic period at higher resolution than the formation subdivision to be compatible with their microfaunal assemblage zones (B1-4, K1-2, R1-5, Nu1-3; Figure 2). We also refer to the work by Krebs et al. (1997) and Wescott et al. (1998) for the sequence labeling (Figure 2). Thirdly, lithologic maps have been established (Figure 4) using sequence stratigraphic correlation and interpreted using constrains from paleoenvironmental data (Hughes et al. 1992; El Beialy et al. 2005) and previous published maps (Nuhkul Fm: Saoudi and Khalil 1984; Khaled et al. 2002; Peijs et al. 2012, Rudeis Fm: Hagras and Slocki 1982; Hughes et al. 1992; Schütz 1994; Bosworth et al. 1998; Gawthorpe et al. 2003; Peijs et al. 2012, Kareem Fm: Hughes et al. 1992; Schütz 1994; Salah and Alsharhan 1997; Khaled et al. 2002; Peijs et al. 2012, Belayim Fm: Khaled et al. 2002, South Gharib/Zeit Fms: Richardson and Arthur 1988). To keep the maps readable, we have only highlighted the deepest part of the basin using the paleo-bathymetry constrains from Hughes et al. (1992). Three main bathymetric ranges were used with: moderately to deep environments (30-100 m in paleo-bathymetry), deep environments (100-200 $\mathrm{m}$ in paleo-bathymetry) and very deep environments (> $200 \mathrm{~m}$ in paleo-bathymetry) (Figure 2, Figure 4). As a result, nineteen lithological maps are presented 
over an updated structural framework. A step by step structural restoration was beyond the of the paleogeography such as sea floor geometry and eroded thicknesses. In a complex area with contrasted reliefs as the Gulf of Suez, the facies and the lateral variations of these facies are the better indicators of these paleogeographies. As a result the 3D restoration cannot be done before the analysis presented here. All the maps are thus shown over the present day structural framework (Figure 4).

Fourthly, isopach / depocenter maps have been established (Figure 5) based on wells and outcrop sections as well as the previous published works using in-house 3D geological modeling tools (Barrois et al. 2010; Barrois 2011).

Finally, mean sediment supply, mean carbonate accumulation rate and mean evaporite accumulation rate were computed from these 3D database (Table 1) using the same methodology proposed by Poag and Sevon (1989), Rouby et al. (2009) and Guillocheau et al. (2012). For each time step, we computed the relative proportion of the lithologies using an automatic image analysis based on the lihtologic maps. The six dominant lithologies have then been gathered into groups to be able to compute an accumulation rate for evaporites (anhydrite and halite), carbonates (carbonates and offshore mudstones) and sediment supply form siliciclastic deposits (shales, sandstones, conglomerates). An optimist, pessimist and preferred scenario have been established to explore the maximum and minimum development for each group of lithology depending on the drawing and extrapolation on the maps (Evaporites, Carbonates and Siliciclastics; Table 1). The preferred scenario corresponds to the lithologic maps presented in Figure 4. Then we estimated the volume for each group of lithology by modulating these relative proportions to the volume of preserved sediment for each time steps (Table 1). Carbonate volumes have been corrected with a porosity of $10 \%$ and siliciclastic volumes with 20\% (e.g. Rouby et al. 2009; Guillocheau et al. 2012). A minimum 
and maximum have also been computed to established error bar on the accumulation rates as well as on the sediment supply (Table 1) and are presented in Figure 6.

\section{STRATIGRAPHIC ARCHITECTURE AND PALEOGEOGRAPHY}

Stacking pattern has been used to correlate the main surfaces at basin-scale and then to characterize the distribution of the main syn-rift formations (Figure 2, Figure 3). The identification of the main facies, environment of deposition (EOD) and depositional profiles is based on the solid sedimentological and environmental knowledge provided by previous studies (e.g. Burchette, 1987; Montenat et al. 1988; Gawthorpe et al. 1990; Hughes et al. 1992; Rouchy et al. 1995; Salah and Alsharhan 1997; Bosence et al. 1998; Gupta et al. 1999; Young et al. 2000; Winn et al. 2001; Jackson et al. 2005; Abd El-Naby et al. 2010; Omran and El Sharawy 2014; Figure 2). Stratigraphic architecture has then been restored by interpreting the sequences using six dominant lithologies: carbonates (including reef and platform s.l. deposits), shales (silty rich from protected to restricted deposits, versus mud rich for offshore deposits), sandstones (including fan delta, shallow marine and turdiditic deposits), conglomerates (including alluvial fan and fan delta deposits), anhydrite and halite (mainly from lagoon and saline to sabkha depositional settings).

\subsection{Nukhul Formation (Miocene, Aquitanian, ca. 20.4-23 Ma)}

The timeframe defined by Hughes et al. (1992) has been used to establish three key phases during the Nukhul Fm deposition (N1 to N3, each of which lasted ca. 0.9 Myr). The main hypothesis for the paleogeographic restoration was that the Shoab Ali Mb was time equivalent to Nukhul Fm deposits in the northern part of the rift, a consistent interpretation with the Bosworth and McClay (2001) review. The Nukhul Fm recorded a progressive flooding from the Mediterranean Sea (Figure 4a-c) with a progressive evolution from supra-littoral to 
moderately deep depositional environments (paleo-bathymetry 30-100 m). Large scale tectonic structures (e.g. accommodation zone, Darag, Central and Southern basins) as well as small scale structures (e.g. tilted block crest, hanging-wall and relay ramp) clearly had an influence onto facies distribution and partitioning (Figure 4a-c). The tilted block crests are commonly surrounded by shallow carbonate deposits while in the hanging-wall setting siliciclastic dominated deposits mainly occurred especially in the Central and Southern basins (Figure 4a-c).

Nu3 (ca. 22.1-23Ma)

The Darag, Central and Southern basins were individualized in terms of depositional environments (Figure 4a). To the south, the Southern basin was characterized by siliciclastic dominated deposits with alluvial fan and fluvio-lacustrine depositional environments. The Morgan accommodation zone was mainly sub-aerial and starved of sediment (Figure 4a). The Central basin was characterized by mixed deposits with shallow marine to restricted deposits. The Zaafarana accommodation zone was characterized by shallow marine deposits recording the transition toward open marine setting to the north (Figure 4a). The Darag basin was thus mainly characterized by open marine deposits (Figure 4a).

Nu2 (ca. 21.2-22.1Ma)

The Darag, Central basins were still individualized in term of depositional environments from the Southern basin showing a N-S depositional gradient (Figure 4b). The marine flooding from the Mediterranean Sea reached the Central basin. The input of siliciclastics decreased relatively to the south in comparison with $\mathrm{Nu} 3$. The depositional profile includes carbonate platforms and isolated reefs along tilted block crests and submerged paleohighs facing moderate to deep basinal marine shales (Darag and Central basins, Figure 4b). The Southern 
basin was characterized by lagoon deposits and marginal marine sabkha evaporites (Figure 4b). There was no clear evidence that the marine flooding originated from the Red Sea to the south.

Nul (ca. 20.4-21.2Ma)

The overall flooding coming from the Mediterranean Sea progressively reached the Morgan accommodation zone (Figure 4c). Deep marine sediments were deposited in the Darag basin (Figure 4c). The input of siliciclastics became progressively localized along the future rift shoulders. Evaporites were preserved in isolated ponds from marginal marine systems in the Southern basin (Figure 4c). There was still no evidence that marine flooding originated from the Red Sea.

\subsection{Rudeis Formation (Miocene, Burdigalian, ca. 15.8-20.4 Ma)}

The periods of time defined by Hughes et al. (1992) has been used to establish four key phases during the Rudeis Fm deposition (R5, R3, R2 and R1). The Rudeis Fm recorded the flooding from both the Mediterranean Sea and the Red Sea and their connection (Figure 4dg). It has recorded the deepest depositional environments (> $200 \mathrm{~m}$ in bathymetry) and a least four main anoxic events (Hughes et al. 1992; Figure 2). Large and small scale tectonic structures influenced facies distribution and partitioning (Figure 3). While during the Nukhul Fm deposition the three main basins were characterized by different depositional setting suggesting a N-S paleogeographic gradient, the Rudeis Fm progressively recorded deep open marine condition all along its axis from the Darag to the Southern basin (Figure 4d-g). The Southern basin and Morgan accommodation zone were preferentially fed by siliciclastics in response to the Precambrian basement denudation, while the Darag basin was mainly characterized by carbonate dominated deposits (Figure 4d-g). Siliciclastics sources were 
distributed all along the rift bounding faults. Very coarse-grained conglomerate sources were localized on the steep relief located on the eastern side of the rift (Figure 4d-g).

$R 5($ ca. 19.6-20.4Ma)

The Rudeis Fm was strongly transgressive onto the Nuhkul Fm with several onlap features indicating a widening of the depocenters (Figure 3). Very deep (200-400 m deep) open marine conditions occurred all along the basin axis with local anoxia (Hughes et al., 1992, Figure 4d). It was the very first time that a marine connection occurred between the Mediterranean Sea and the Red Sea (Figure 4d). The input of siliciclastics was mainly localized along the rift shoulders and most of the tilted block crests were progressively onlapped by carbonate reefs and platforms (Figure 4d). Sandstones were locally delivered to the basin axis throughout the main accommodation zones (Morgan and Zaafarana) and smaller relay ramp areas (e.g. BabaBelayim area, Figure 4d). The R5 period of time is interpreted as the overall maximum flooding event during the rift evolution (Figure 2).

R3 (ca. 17.6-18.5 Ma)

The trend initiated during the previous stage continued with very deep open marine conditions all along the basin axis and input of siliciclastics along the rift shoulders (Figure 4e). The R3 period of time recorded the widest spread and thickest distal offshore deposits (Figure 4e), with very deep (200-400 m deep) open marine conditions characterized by another major anoxic event (Hughes et al., 1992; Figure 2).

$R 2($ ca. 16.7-17.6 Ma)

The R2 period of time (equivalent to the basal portion of the Upper Rudeis) marked a major change during the rift evolution (Figure 4f), traditionally related to the mid-Clysmic event 
(Garfunkel and Bartov 1977). A major increase in the sediment supply from the eastern rift

\subsection{Kareem Formation (Miocene, Langhian, ca. 13.6-15.8 Ma)}

We mainly refer to the work done by Hughes et al. (1992), Salah and Alsharhan (1997) and El Beialy et al. (2002) to establish four key phases during the Kareem Fm deposition (Figure 4hk). The Kareem Fm recorded the progressive disconnection between the Mediterranean Sea and the Red Sea (Figure 4h-k). Deep to very deep water depositional environments were

The forced regressive trend initiated during the previous stage continued (Figure 4g). The R1 period of time recorded the last major anoxic event during the rift evolution (Hughes et al. 1992; Figure 2). A progressive decrease in paleo-bathymetry and a change in sea bottom conditions have been inferred from the benthonic foraminifera assemblages (Hughes et al. 1992; Figure 2). The R1 deposits are organized in an overall prograding trend up to the first major sequence boundary (T30, boundary between Rudeis and Kareem Formations) recorded at basin-scale (e.g. Figure 3d, massive sandstone package organized in a forced regressive trend along well 47). 
developed (> $200 \mathrm{~m}$ in bathymetry), nevertheless, the Kareem Fm constitutes a transition toward mainly oxic paleoenvironmental conditions (Hughes et al. 1992; Figure 2). Large scale tectonic structures had a major influence onto facies distribution and partitioning (Figure 4hk). As for the previous period of time (Rudeis Fm), siliciclastics were mainly preserved in the Southern basin, Morgan accommodation zone and along the rift bounding faults.

K2 - basal Markha (ca. 15.3-15.8 Ma)

The K2 - basal Markha deposits overlaid a major sequence boundary (T30 ca. 15.8 Ma;

Figure 2, Figure 3). Open marine conditions still prevailed in the northern part of the rift (Darag basin and Zaafarana accommodation zone) and the southernmost part (SE of the Southern basin). Very large carbonate platforms occurred in the Southern basin and along the Zaafarana accommodation zone (Figure $4 \mathrm{~h}$ ). The Central basin was characterized by large and thick anhydrite deposits laterally passing to shallow marine carbonates to the north and to the south east (Figure 4h). This paleogeographic configuration thus recorded the first evidence during the syn-rift deposition of disconnection between the Mediterranean Sea and the Red Sea (Figure 4h). Rift shoulders still constituted the main source areas for siliciclastics (Figure 4h).

K2 - Middle Markha (ca. 14.8-15.3 Ma)

The K2 - Middle Markha deposits recorded a new major flooding from both the Mediterranean Sea and the Red Sea (Figure 4i). Depositional environments and lithology distributions were very similar to those occurring during the deposition of the R3-Rudeis Fm deposits with neither evidences of anoxic nor suboxic conditions (Figure 2) as paleobathymetry was relatively lower (Figure 4i). 
K2/K1 transition - Markha/Shagar (ca. 14.3-14.8 Ma)

The K2/K1 transition - Markha/Shagar deposits recorded another major disconnection between the Mediterranean Sea and the Red Sea. As for the K2 - basal Markha deposits, open marine conditions only prevailed in the northern part and the southernmost part of the Suez rift (Figure 4j). The Zaafarana accommodation zone controlled the occurrence of a large carbonate platform recording the transition from open marine setting to the north to a restricted setting in the Central basin (Figure 4j).

K1 - Top Shagar (ca. 13.6-14.3 Ma)

The K1 - Top Shagar deposits recorded a major flooding event occurring at basin-scale (Figure 4k). Isolated platforms were very small and restricted to tilted block crests (Figure 4k). Siliciclastic were mainly derived from the rift shoulders, especially in the Southern basin and along the Morgan accommodation zone (Figure 4k). The topmost part of K1 - Top Shagar deposits are organized in an overall prograding trend up to the second major sequence boundary recorded at basin-scale (T50 ca. 13.6 Ma; Figure 2, Figure 3).

\subsection{Belayim Formation (Miocene, Serravallian, ca. 11.8-13.6 Ma)}

The periods of time defined by Hughes et al. (1992) have been used to establish four key phases during the Belayim Fm deposition (B4, B3, B2 and B1). The Belayim Fm recorded a progressive disconnection between the Mediterranean Sea and the Red Sea in the Suez rift (Figure 41-o). It has recorded the first thick and widely distributed salt deposits over the Suez rift (Figure 3, Figure 41). The Belayim Fm also illustrates the full depositional profile from open marine setting in the south (Southern basin) to restricted environments with a lateral facies change from anhydrite to halite in the north (Darag basin, Figure 41 and n). Small scale tectonic structures had influence onto facies distribution (e.g. faulted controlled depocenters 
with halite on Figure 41). The input of siliciclastic was mainly localized along the Morgan accommodation zone and in the Central basin (Figure 4l-o).

B4 - Baba (ca. 13.1-13.6 Ma)

The B4 - Baba deposits recorded the first disconnection of the entire Suez rift from the Mediterranean Sea and an overall restriction of the Darag, Central and Southern basins (Figure 4l). Halite deposits were preserved in fault controlled depocenters (Figure 4l). Sediment supplies along the rift shoulders were very low as suggested by the very small isolated siliciclatics bodies (e.g. Wadi Araba, Belayim and Baba areas; Figure 4l). A large carbonate platform was developed to the south of the Southern basin, recording the transition toward more open marine setting in the Rea Sea to the south (Figure 41).

B3 - Sidri (ca. 12.6-13.1 Ma)

The B3 - Sidri deposits (as the top Shagar) recorded one of the last flooding events occurring at basin-scale in the Suez rift (Figure 4m). The Southern basin was characterized by a restricted environment along its western part (Zeit area), while open marine conditions prevailed along a north to south corridor to the east (Figure $4 \mathrm{~m}$ ). Siliciclastic supplies were mainly localized in the Central basin and along the Morgan accommodation zone where the Precambrian basement was denudated (Figure $4 \mathrm{~m}$ ).

B2 - Feiran (ca. 12.1-12.6 Ma)

The B3 - Feiran deposits recorded a second full disconnection from the Mediterranean Sea as the B4 - Baba deposits (Figure 4n). Halite deposits were preserved in fault controlled depocenters in the Southern basin and along the Morgan accommodation zone suggesting less intense evaporation processes in the Central basin compared to the B4 - Baba period of time 
(Figure 41). Very small isolated siliciclatics bodies were preserved especially in the Wadi Araba, Belayim and Baba areas (Figure 4n). As for the B4 - Baba deposits, a large carbonate platform was developed to the south of the Southern basin (Figure 4n).

\section{B1-Hammam Faraun (ca. 11.8-12.1 Ma)}

The B1 - Hammam Faraun deposits recorded the very last marine flooding event occurring at basin-scale connecting the Mediterranean Sea and the Red Sea (Figure 4o). Paleogeographic setting was very similar to the B3 - Sidri period of time, with restricted and shallow environments in the Zeit area and isolated inputs of siliciclastics (Wadi Araba, Morgan Accommodation zone, Belayim and Baba areas; Figure 4o). The restricted depositional environments preserved to the east of the Darag basin and the open marine deposits to the north were the last sedimentary records before a long period of erosion and/or non-deposition to the north of the Suez rift (Figure 4o).

\subsection{South Gharib Formation (Miocene, Tortonian, ca. 7.2-11.8 Ma)}

No high resolution biostratigraphic constraints for the South Gharib Fm were available as the ones provided by Hughes et al. (1992) for the previous formations. We thus choose to highlight only two key phases during the deposition of the South Gharib Fm: its lowermost and uppermost parts. The three main basins were characterized by a north to south paleogeographic gradient with highly evaporitic setting to the south and more siliciclastic and mixed setting to the north (Figure 4p-q). Halite deposits were preserved in fault controlled depocenters (Figure 3, Figure 4p-q). The input of siliciclastic was spatially localized and almost corresponded to the present day feeding points (Figure 4p-q). Evaporation processes were the dominant sedimentary processes. 


\section{Lower South Gharib (ca. 9.5-11.8 Ma)}

The Lower South Gharib deposits overlaid a major sequence boundary (T60 ca. 11.8 Ma;

Figure 2, Figure 3). For the very first time, anhydrite and halite deposits occupied the whole of the Suez rift (Figure 4p). Fault controlled depocenters characterized by halite deposits were connected into very large depocenters in the Southern basin up to the Morgan accommodation zone (Figure 4p). The Central basin and the Zaafarana accommodation zone were characterized by anhydrite deposits with fault controlled halite deposits, recording the transition toward the Darag basin where only condensed siliciclastic deposits were preserved (Figure 3, Figure 4p). There were no preserved deposits in the northern part of the Darag basin (Figure 3, Figure 4p).

\section{Upper South Gharib (ca. 7.2-9.5 Ma)}

The Upper South Gharib deposits were organized in a similar trend as the South Gharib deposits with highly evaporitic setting to the south (Figure 3, Figure 4q). The Southern and Central basins were characterized by fault controlled halite depocenters connected by very continuous anhydrite deposits (Figure 4q). The inputs of siliciclastics were localized along the main feeding points already active during the deposition of the Lower South Gharib (Figure $4 q)$. The size of the fan systems was much larger than during the deposition of the Lower South Gharib suggesting an increase in the water supplies coming from the catchment areas (Figure 4q).

\subsection{Zeit Formation (Miocene, Messinian, ca. 5.3-7.2 Ma)}

As it happens for the case of the South Gharib Fm, no high resolution biostratigraphy was available for the Zeit Fm so it was subdivided into a lower and an upper part (Figure 4r-s). The same paleogeographic gradient as for the South Gharib Fm deposition was identified with 
highly evaporitic setting to the south (Figure 3, Figure 4r-s). Halite and/or anhydrite deposits were preserved in fault controlled depocenters (Figure 4r-s). The input of siliciclastic was spatially localized and almost corresponds to the present day feeding points (Figure 4r-s). Evaporation processes were still important, but the input of siliciclastics increased as well as mixed carbonate dominated deposits compared to the South Gharib period of time suggesting more humid climatic setting (Figure 3, Figure 4r-s).

\section{Lower Zeit (ca. 6.2-7.2 Ma)}

The Lower Zeit deposits recorded a period of relatively low occurrence of evaporate deposits during the Tortonian-Messinian time interval (Figure 4r). Small isolated evaporitic depocenters occurred in the Central and Darag basins mainly filled with anhydrite and few halite deposits (Figure 4r). The Southern basin was characterized by fault controlled halite small depocenters connected by very continuous anhydrite deposits (Figure 4r). Siliciclastic supplies were the highest during the Tortonian-Messinian time interval (Figure 6). There were no deposits preserved in the northern part of the Darag basin (Figure 3, Figure 4r).

\section{Upper Zeit (ca. 6.2-5.3 Ma)}

The Upper Zeit deposits recorded another pulse in evaporitic conditions, almost equivalent to the Upper South Gharib Fm in term of spatial distribution (Figure 4s). Two large fault controlled depocenters with halite were preserved in the Central basin. The Southern basin was still characterized by small fault controlled depocenters with halite and continuous anhydrite deposits (Figure 4s). Siliciclastic supplies were still high with large localized fan system (Figure 4s). No deposits from this age were preserved in the northern part of the Suez rift (Figure 4s). 


\section{RIFT DYNAMICS, SUBSIDENCE AND UPLIFT}

The presented stratigraphic architecture restoration (Figure 3, Figure 4) has been then combined to thickness and depocenter maps analysis (Figure 5) and discussed in the light of the subsidence and uplift dynamics within the rift evolution taking into account the published subsidence analysis (Steckler 1985; Moretti and Colletta 1987; Moretti and Chenet 1987; Richardson and Arthur 1988; Figure 6). The total amount of uplift/exhumation during the rift evolution has been estimated to about 5-7 km on the western rift shoulder (Omar et al. 1989).

\subsection{Rift initiation (Oligocene, Chattian. ca. 1-4Myr duration)}

Faunas, stratigraphic relationships, K-Ar and Ar-Ar dates indicate that the onset of the rifting is no younger than 25-27 Ma in the Southern basin area (e.g. El Shinnawi 1975; Purser and Hötzl 1988), 23-25 Ma for the Central basin area (e.g. Plaziat et al. 1998) and ca. 23.5 Ma for the Darag basin and the Cairo-Suez areas (Kappelman et al. 1992; Lotfy et al. 1995) suggesting a rift propagation toward the north that is consistent with recent observation from the Nile delta (Sarhan et al. 2014).

Two preserved depocenters 50-60 km wide are localized over the future main Southern and Central domains of the Suez rift (Figure 5a). To the North, there is no data from the Darag basin depocenter to illustrate Oligocene deposits but only few witnesses in the northernmost part of the Suez rift (Figure 5a). The central part is also characterized by volcanism along the rift shoulders and rift axis (Figure 5a). Basaltic dikes, sills and flows have sub-alkaline to alkaline affinities and have been interpreted to be diagnostic of intraplate, tensional environment (Moussa 1987).

Subsidence was very low during the Late Oligocene (Steckler 1985; Moretti and Colletta 1987; Richardson and Arthur 1988) and reliefs mainly corresponded to inherited topography from the Syrian Arc such as the Wadi Araba structure (Garfunkel 1988; Evans 1990; Khaled 
et al. 2002; Figure 1). Basement was already exposed to the South (present day Red Sea) by late Oligocene times (Thiriet 1987). The onset of rift-related uplift in Sinai has been proposed around 26.6 +/- 3 Myr based on Fission Track Analysis (Kohn and Eyal 1981).

\subsection{Rift widening (Miocene, Aquitanian, ca. 3Myr duration)}

The presence of growth-strata in the Nukhul Fm indicates that extensional faults were active during the Aquitanian (e.g. Colletta et al 1988; Jackson et al. 2002). The rift was subdivided into numerous depocenters (Figure 5b) controlled by active faults recording a progressive fault linkage and interaction (e.g. Leeder and Gawthorpe 1987; Gawthorpe et al. 1997; Khalil and McClay 2002; Jackson et al. 2002). Meanwhile, some former faults were abandoned. This first major phase of extension was characterized by a low tectonic subsidence $(0-100 \mathrm{~m} / \mathrm{Myr}$, Moretti and Colletta 1987; Richardson and Arthur 1988). The Nubia Sandstones and the crystalline basement were the main feeding sources for sediment delivery into the Southern basin. Scarce boulder conglomerates and breccias suggest high local relief in the Central basin as well as in the Southern basin (e.g. Richardson and Arthur 1988; Patton et al. 1994; Winn et al. 2001), that is consistent with the initiation of basement uplift along the western margin of the Gulf of Suez between 21 and 23 Ma based on fission track analysis (Omar et al. 1989). These very coarse-grained deposits could also be locally related to fault block rotation and exposure of the footwall crests. Sedimentological and structural evidences suggest an overall subdued topography with perhaps only a few hundreds of meters relief that is consistent with previous works (Garfunkel and Bartov 1977; Sellwood and Netherwood 1984).

\subsection{Rift climax (Miocene, Burdigalian, ca. 5Myr duration)}

Rotation and uplifting of fault blocks as well as renewing subsidence were recorded all over the basin during the latest Aquitanian-earliest Burdigalian period of time (Post Nukhul Event; 
Garfunkel and Bartov 1977; Beleity 1984; Chenet et al. 1984). The rift was subdivided into some major basins controlled by active faults highlighting the three main domains of the Suez rift (Figure 5c). Fault linkage still occurred. Tectonic subsidence rates increased (up to 250 $\mathrm{m} / \mathrm{Myr}$ ) and the total subsidence rates were as high as $400 \mathrm{~m} / \mathrm{Myr}$ in the deeper, more rapidly subsiding grabens (Moretti and Colletta 1987; Richardson and Arthur 1988). Subsidence rates in the Gulf of Suez reached their maximum during the Burdigalian and occurred across the entire rift basin (Steckler 1985; Moretti and Colletta 1987; Moretti and Chenet 1987;

Richardson and Arthur 1988). Concomitantly, the shoulders of the rift, including the Sinai Massif and Red Sea Hills, underwent rapid uplift (Garfunkel and Bartov 1977; Garfunkel 1988).

The mid-Clysmic event is interpreted as a major tectonic reactivation in the rift which involved the segmenting and rotation of major pre-existing tilted blocks into smaller units (Garfunkel and Bartov 1977). To the north of the Suez rift, tectonic subsidence ceased completely (Moretti and Colletta 1987; Richardson and Arthur 1988). It corresponds to a major pulse in siliciclastics (at least two times the mean sediment supply during the whole rifting, Figure 6). Moreover, the sediment supply pulse is probably underestimated in our study as we used a duration of 0.9 Myr for R1 and R2 following a simple linear interpolation for the duration of each phases during the Rudeis Fm deposition, while a 0.5 Myr duration would be more likely. It is also concomitant with a major eustatic sea level fall (Gradstein et al. 2012).

\subsection{Late syn-rift to rift narrowing (Miocene, Langhian-Serravalian, ca. 4Myr duration)}

During the Langhian, the rift was subdivided into several main depocenters controlled by active faults that were superimposed onto the previous Rudeis depocenters (Figure 5d). New 
additional depocenters localized along the rift margin suggest a widely distributed and overall basinal subsidence (Figure 5d).

The Rudeis to Kareem transition ( early Langhian) was characterized by a major decrease of the extension rate, especially in the vicinity of Hurghada from 0.48 to $0.18 \mathrm{~cm} / \mathrm{yr}$ (Steckler et al. 1988). The former reliefs induced during the rift climax were quickly destroyed as evidenced by the drastic drop in sediment supply (Figure 6). Stratigraphic architecture along the eastern margin suggests that some of the main border faults became inactive and fault activity migration toward the basin axis (e.g. Baba area; Figure 3, Figure 4).

The Kareem to Belayim transition ( late Langhian) was then characterized by another major decrease of the extension rate from 0.18 to $0.05 \mathrm{~cm} / \mathrm{yr}$ (Steckler et al. 1988). Subsidence analysis also indicates a sudden drop in subsidence rates at the end of the Kareem Fm deposition (Moretti and Colletta 1987; Richardson and Arthur 1988). During Serravalian times, the rift was subdivided into several main depocenters mainly localized along the present day basin axis (Figure 5e). While tectonic subsidence rate was almost negligible during Serravalian times, accommodation space creation was mainly controlled by sediment loading (Moretti and Colletta 1987) along the basin axis indicating a major rift narrowing (Figure 5e, Figure 6).

\subsection{Tectonic quiescence to latest syn-rift (Miocene, Tortonian-Messinian, ca. 7Myr duration)}

The basin was still subdivided into several sub-basins bounded by major faults already well developed during the previous rift narrowing stage (Figure 5f, 5g). Tectonic subsidence was negligible and accommodation space creation was mainly controlled by sediment loading (Moretti and Colletta 1987; Richardson and Arthur 1988). To the north of the Suez rift, 
tectonic uplift could have occurred (Richardson and Arthur 1988). Sedimentary patterns and fauna indicate that the rift was definitively disconnected from the Mediterranean Sea.

\section{DISCUSSION}

\section{Rift evolution and sediment supply}

The large scale evolution of the Suez rift is consistent with other published models for rift evolution with a (1) Rift Initiation, (2) Rift widening, (3) Rift climax, (4) Late syn-rift to rift narrowing and (5) Tectonic quiescence to latest syn-rift (Leeder and Gawthorpe 1987; Prosser 1993; Lambiase and Bosworth 1995; Gawthorpe and Leeder 2000). Our study provides some additional constraints in terms of timing and erosion/sedimentation dynamics within the rift evolution (Figure 6). The mass balance analysis indicates that the rift shoulder dynamic includes a growth phase lasting 6-7 Myr recorded by an rapid and progressive increase in sediment supply (Figure 6). Relief then reached its topographic maximum as suggested by the maximum sediment supply (Latest Rudeis Fm, R5). Finally, the rapid and abrupt decrease in sediment supply (ca. 1Myr) during the transition from the Rudeis Fm to Kareem Fm, was followed by a progressive decrease (ca. $<3.5 \mathrm{Myr}$ duration, Kareem to Belayim Fms) to reach a very low value during the South Gharib Fm deposition. This final evolution can be interpreted as a "relief destruction" phase. This sediment supply dynamic at rift scale is consistent with analog and numerical modeling (growth phase, optimum and destruction phase), clearly indicating that this sediment supply dynamics was tectonically driven (e.g. Lague et al. 2003, Bonnet and Crave 2003, Rohais et al. 2012).

This result has a major impact onto the understanding of flank retreat dynamic during post-rift evolution. Indeed, most of the concept and modeling approaches addressing flank retreat issue are based on a starting boundary condition using former rift topography (e.g. van der Beek et al. 1994; Brown et al. 2002; Japsen et al. 2011). In our study, the sediment supply dynamic 
indicate that the latest syn-rift phase was characterized by low relief with very localized inputs of siliciclastics (Figure 4, Figure 6). This point could be considered as a major challenge in some future works. Typically, in the Suez rift, the present day topography is potentially related to the post-rift dynamics.

\section{Suez rift and geodynamic setting}

At $14 \mathrm{Ma}$ (Langhian), the Aqaba transform boundary cut through Sinai and the Levant continental margin (Figure 1), linking the northern Red Sea with the Bitlis-Zagros convergence zone (e.g. Bosworth et al. 2005; Gvirtzman and Steinberg 2012). Extension in the Suez was reduced and then stopped (e.g. Moretti and Colletta 1987; Steckler et al. 1988) suggesting that the mechanism responsible for the Suez rift opening was no more active. Meanwhile, the opening of the Red Sea continued until became an ocean during the Pliocene. Extension in the Suez rift has been previously reduced during the Langhian times in response to the collision of Arabia and Eurasia (Dercourt et al., 1986; Le Pichon and Gaulier 1988). The Aqaba transform boundary (Figure 1) could thus be interpreted as an accommodation fault between the continuous extensional processes in the southern Red Sea and an abandoned extensional segment in the north corresponding to the Suez rift. It suggests that the deep source controlling the extension in the Suez rift is not below the rift, but below the Red Sea. This is very consistent with a south to north propagation of the Suez rift as documented in our reconstruction (Figure 4).

\section{Evaporite in rift basin}

Evaporite deposition is generally controlled by the combined effect of (1) the hydrologic balance, or aridity index and (2) the isolation of the basin characterized by the interaction between sill and sea level (e.g. Warren 2010). Regarding the aridity, a global cooling and 
drying at about 15.6 Ma (i.e. Langhian) occurred in northeastern Africa (Kennett, 1995). In the late Tortonian - Early Messinian (ca. $8 \mathrm{Ma}$ ) relatively more humid conditions occurred in an overall arid setting (Griffin, 1999), that is consistent with our reconstructions for the Zeit Fm (Messinian). During the Plio/Pleistocene northeastern Africa was still subjected to alternating dry and wet periods (Griffin, 1999; 2002). Aridification was thus a criterion satisfied for evaporite deposition in the Suez rift starting from the Langhian times.

The main sills were in the north of the Darag basin and across the Zaafarana and Morgan accommodation zones (Figure 1). The first evidence for the isolation of the Suez rift occurred during the Langhian (Kareem Fm) with a progressive paleo-bathymetry decrease along the basin axis (Darag, Central and Southern basins) and the occurrence of a large platform across the Central basin (Figure 4h-j). This "Plaform Evaporite" sensu Warren (2010) has progressively been widened to finally reach a "Basinwide Evaporite" sensu Warren (2010) configuration during the Serravalian times (Belayim Fm). Finally, the main sill controlling the disconnection of the Mediterranean Sea from the Red Sea were located in the north of the Darag basin during the Tortonian to Messinian times (Figure 4). It indicates that the first sills to interact with the sea level changes were related to rift structures: the Zaafarana and Morgan accommodation zones. Finally, a sill on the northern edge of the Suez rift was the dominant structure controlling the connection between Mediterranean Sea and the Red (Figure 4). The pre-salt to salt transition in the Suez rift can thus be interpreted as a sedimentary record of the combined effect of a climate change (including aridity) and the rift dynamic that lasted for ca. 4 Myr. Finally, the occurrence of long lasted and widespread evaporite series where controlled by both two major external controlling factors: climate and geodynamic (rift abandonment).

\section{Rift dynamic and sequence stratigraphy}


A typical rift sequence can be derived from this basin-scale study. The Nukhul Fm with dominantly shallow water deposits can be interpreted as the records of the filled phase, the Rudeis Fm with its well-developed turbiditic packages as the underfilled phase, the Kareem and Belayim Fms with their prograding patterns and progressive evolution toward shallow water deposits as a filled phase and finally the South Gharib and Zeit Fms with the alluvial to sabkha deposits as overfilled phase. During filled and overfilled phases, a longitudinal N-S depositional gradient prevailed (Figure 4). This tectonically-controlled stratigraphic framework can be correlated to a second-order cycle, i.e. 18-20 Myr duration cycle. This cycle can be interpreted in a transgressive, highstand and lowstand system tracts sensu Catuneanu et al. (2009). At higher resolution, the highstand system tract (Rudeis, Kareem and Belayim Fms) can be subdivided into one basal highstand (Lower Rudeis Fm) overlain by a falling stage system tract (Upper Rudeis, Kareem and Belayim Fms, Figure 2). This falling stage system tract can be subdivided into two third order sequences including two major aggrading-prograding packages that can be interpreted as lowstand system tract (RahmiMarkha Mb. and Baba-Sidri-Feiran Mbs.; Figure 2). Duration and timing of these major third order sequences are correlated with the main tectonic stage identified for the rift evolution. The typical rift sequence thus includes: a (1) Rift Initiation, rapid flooding and major transgressive surface, (2) Rift widening, transgressive system tract, (3) Rift climax, highstand system tract and condensed sections, (4) Late syn-rift to rift narrowing, falling stage system tract and (5) Tectonic quiescence to latest syn-rift, lowstand system tract. At higher resolution, i.e. fourth and higher order sequences, the whole cycle is not always easily identified. Sequence boundaries are often superimposed by sharp flooding surface rapidly overlain by a prograding and shallowing upward packages interpreted as highstand system tract (Figure 2). These fourth and higher order sequences could thus be related to stage of activity during the fault growth. 


\section{CONCLUSION}

Stratigraphic architecture reconstruction have been carried out to propose a basin-scale model evolution for the pre-salt to salt syn-rift fill of the Suez rift. Four main results can be highlighted from our study:

First, the key periods of time during a rift evolution have been recognized and their durations have been estimated with (1) a rift initiation or onset of the rifting stage (ca. 1-4 Myr duration) with active volcanism and isolated depocenters, (2) a rift widening stage (ca. $3 \mathrm{Myr}$ duration) with a progressive marine flooding and fault propagation, (3) a rift climax (ca. 5 Myr duration) characterized by several major anoxic events, maximum fault throw and subsidence rate, increasing and maximum sediment supply from the rift evolution, (4) a late syn-rift to rift narrowing (ca. 4 Myr duration) characterized by a progressive smoothing of the paleogeography with low to no more active tectonic uplift/erosion along the rift shoulders combined with a reducing paleo-bathymetry along the basin axis, (5) and finally a tectonic quiescence phase (ca. 7 Myr duration) characterized by a thick salt series.

Second, the sediment supply dynamics during rifting is characterized by (1) progressive increase up to its (2) maximum, (3) rapid and abrupt decrease (less than 1Myr) and finally (4) very progressive decrease that can be interpreted as a (1) relief growth, (2) optimum and $(3,4)$ destruction phases related to uplift dynamic.

Third, the pre-salt to salt transition in the Suez rift is interpreted as the sedimentary record of the combined effect of a climate and rift dynamic changes. The Central basin, Zaafarana and Morgan accommodation zones were the first main divides between the Mediterranean Sea and the Red Sea.

Fourth, several order of sequences can be recognized in the syn-rift fill with fourth to higher order sequences related to fault activity, third order sequences related to (sub-)basin dynamics 
(Darag, Central and Southern basins) and second order sequences related to the whole rift basin dynamic (Suez rift).

The proposed geological scenario with quantified sediment supply, accumulation rate,

lithologic distribution and subsidence dynamics could be used to test modeling approaches of the relationship between deep and surface processes in future works.

\section{Acknowledgements}

This project could not have been accomplished without the very large database acquired by IFPEN during the last 30 years in the frame of collaborative partnerships. The authors would like to thank the two anonymous reviewers for their valuable suggestions and reviews of the initial manuscript. 
Abdelghany O (2002) Lower Miocene stratigraphy of the Gebel Shabrawet area, north Eastern desert Egypt. Journal of African Earth Sciences 34 (2002) 203-212

Abd El-Naby AIM, Ghanem H, Boukhary M, Abd El-Aal M, Lüning S, Kuss J (2010) Sequence-stratigraphic interpretation of structurally controlled deposition: Middle Miocene Kareem Formation, southwestern Gulf of Suez, Egypt: GeoArabia., 15(3): 129-150

Abd El Shafy A (1990) Miocene-Pliocene boundary in the Gulf of Suez region, Egypt. 10th EGPC Exploration Seminar, Cairo, Egypt, 1:213-233

Allen G, Ayyad A, Desforges G, Haddadi M, Pizon J (1984) Subsurface sedimentological study of the Rudeis Formation in Kareem, Ayun, Yusr and Shukheir fields, in Proceedings of the 6th Exploration Conference: Cairo, Egyptian General Petroleum Corporation, p. 164-176

Artushkov E and Baer M (1984) Mechanism of continental crust subsidence in the Alpine Belt. Tectonophysics, V 108, 193-228

Barrois A (2011) Couplage d'un modèle structural 3D restauré (Kiné3D-3) avec un modèle de remplissage stratigraphique (Dionisos) en contexte extensif, cas du rift de Suez (Égypte). I.F.P. report 62044

Barrois A, Rohais S, Granjeon D, Rudkiewicz JL, Cacas MC (2010) Coupling 3D Structural Restoration with Stratigraphic Modelling in Rifted Margins, Suez Rift, Egypt. International conference "Modelling sedimentary basins and their petroleum systems", June 3-4th 2010, Geol. Soc. London

Beleity AM (1984) The composite standard and definition of paleogeography and paleotectonics in the Gulf of Suez. In Egyptian General Petroleum Corporation. 6th EGPC Exploration Conference, Cairo, Egypt, 181-198

Bonnet S and Crave A (2003) Landscape response to climate change: insights from experimental modeling and implications for tectonic vs. climatic uplift of topography. Geology 31: 123-126

Bosence DWJ, Cross NE, Hardy S (1998) Architecture and depositional sequences of Tertiary fault-block carbonate platforms; an analysis from outcrop and computer modelling. Mar Pet Geol;15:203- 21

Bosworth W (1995) A high-strain rift model for the southern Gulf of Suez. Egypt. In J.J. Lambiase (Ed.), Hydrocarbon habitat in rift basins. Geological Society, London, special publication no. 80 , p. $75-112$

Bosworth W, Crerello P, Winn Jr RD, Steinmetz J (1998) Structure, sedimentation, and basin dynamics during rifting of the Gulf of Suez. In: Purser BH, Bosence DWJ (eds) Sedimentation and tectonics of rift basins: Red Sea-Gulf of Aden. pp. 78-96

Bosworth W and McClay K (2001) Structural and stratigraphic evolution of the Gulf of Suez rift, Egypt: a synthesis. In: Ziegler PA, Cavazza W, Roberston AHF, Crasquin-Soleau S (eds) Peri-Tethys Memoir 6: Peri-Tethyan rift/wrench basins and passive margins. p. 567-606 
Bosworth W, Huchon P, McClay K (2005) The Red Sea and Gulf of Aden Basins. J. Afr. Earth Sci. 43, 334-378

Brown RW, Summerfield MA, Gleadow AJW (2002) Denudational history along a transect across the Drakensberg Escarpment of southern Africa derived from apatite fission track thermochronology. J. Geophys. Res.-Solid 107, 74-77

Bunter MAG (1980) Gulf of Suez Stratigraphic Summary, CONOCO Internal Report

BurchetteTP (1987) Tectonic control on carbonate platform facies distribution and sequence stratigraphy: Miocene, Gulf of Suez. Sedimentary Geology, v. 59, p. 179-204

Burov EB and Poliakov ANB (2001) Erosion and rheology controls on syn-and post-rift evolution: Verifying old and new ideas using a fully coupled numerical model, J. Geophys. Res., 106, 16,461-16,481

Catuneanu O, Abreu V, Bhattacharya JP, Blum MD, Dalrymple RW, Eriksson PG, Fielding CR, Fisher WL, Galloway WE, Gibling MR, Giles KA, Holbrook JM, Jordan R, Kendall CGStC, Macurda B, Martinsen OJ, Miall AD, Neal JE, Nummedal D, Pomar L, Posamentier HW, Pratt BR, Sarg JF, Shanley KW, Steel RJ, Strasser A, Tucker ME, Winker C (2009) Towards the Standardization of Sequence Stratigraphy. Papers in the Earth and Atmospheric Sciences. Paper 238

Chaboureau AC, Guillocheau F, Robin C, Rohais S, Moulin M, Aslanian D (2013)

Paleogeographic evolution of the central segment of the South Atlantic during Early Cretaceous times: paleotopographic and geodynamic implications. Tectonophysics 604, 191223

Chenet PY (1984) Tectonics of the Suez rift; structural analysis of the Nukhul area. I.F.P. report $n^{\circ} 32118$

Chenet PY, Letouzey J, Zaghloul E (1984) Some observations on the rift tectonics in the eastern part of the Suez rift. Proceedings of the 7th Egyptian General Petroleum Corporation Exploration Seminar, Cairo, Egypt 1984:18-36

Chowdhary LR, Shaheen S, Naggar AA (1986) Structure and structural evolution of Ras Budran, Gulf of Suez, Egypt. 8th E.G.P.C. Explor. Conf.. Cairo. Preprint.

Cloetingh S, Tibaldi A and Burov E (2012) Coupled Deep Earth and surface processes and their impact on geohazards. Global and Planetary Change 90-91 (2012) 1-19. doi:10.1016/j.gloplacha.2012.01.010

Colletta B, LeQuellec P, Letouzey J, Moretti I (1988). Longitudinal evolution of the Suez rift structure (Egypt). Tectonophysics 153, 221-233

Cowie PA, Gupta S, Dawers, NH (2000) Implications of fault array evolution for syn-rift depocentre development: insights from a numerical fault growth model. Basin Research, 12: 241-261. doi:10.1111/j.1365-2117.2000.00126.x 
Dercourt J, Zonenshain LP, Ricou LE, Kazmin VG, Le Pichon X, Knipper A, Grandjacquet C, Shortshikov IM, Geyssant J, Lepvrier C, Perchersky DH, Boulin J, Sibuet J-C, Savostin LA, Sorokhtin O, Westphal M, Bazhenov ML, Lauer JP, Biju-Duval B (1986) Geological evolution of the Tethys belt from the Atlantic to the Pamirs since the Lias. Tectonophysics $123,241-315$

El Beialy SY and Ali AS (2002) Dinoflagellates from the Miocene Rudeis and Kareem formations borehole GS-78-1, Gulf of Suez, Egypt. Journal of African Earth Sciences, 35, 235-245.

El Beialy SY, Mahmoud MS, Ali AS (2005) Insights on the age, climate and depositional environments of the Rudeis and Kareem formations, GS-78-1 well, Gulf of Suez, Egypt: A Palynological Approach. Revista Española de Micropaleontología., 37(2): 273-289

El Shinnawi MA (1975) Planktonic foraminifera from the Miocene Globigerina Marl of Hurgada Well-134, Eastern Desert, Egypt. In: Mineras ENAdI (ed) 5th African Colloquium on Micropalaeontology, Addis Ababa, pp 199-224

Egyptian General Petroleum Corporation, EGPC (1964) Oligocene and Miocene rockstratigraphy of the Gulf of Suez region, report of the Stratigraphic Committee: Egyptian General Petroleum Corporation, $142 \mathrm{pp}$

Evans AL (1988) Neogene tectonic and stratigraphic events in the Gulf of Suez rift area, Egypt. Tectonophysics 153:235-247

Evans AL (1990) Miocene sandstone provenance relations in the Gulf of Suez: Insights into syn-rift unroofing and uplift history, AAPG Bull., 74, 1386-1400

Fawzy H and Abdel Aal A (1984) Regional study of Miocene evaporates and Pliocene-recent sediments in the Gulf of Suez. In Egyptian General Petroleum Corporation. 7th EGPC Exploration Seminar, Cairo, Egypt, 49-74

Fleitout L and Yuen D (1984) Steady State secondary convection beneath lithospheric plates with temperature and pressure dependent viscosity. JGR, 89, 9227-9244

Garfunkel Z and Bartov Y (1977) The tectonics of the Suez rift. Geol Surv Isr Bull 71:45

Garfunkel Z (1988) Relation between continental rifting and uplifting: evidence from the Suez rift and northern Red Sea. Tectonophysics, v. 150, pp. 33-49

Gargani J, Moretti I, Letouzey J (2008) Evaporite accumulation during the Messinian Salinity Crisis: The Suez Rift case, Geophys. Res. Lett., 35, L02401, doi:10.1029/2007GL032494

Gawad WA, Gaafar I, Sabour AA (1986) Miocene stratigraphic nomenclature in the G.O.S. region. $8^{\text {th }}$ E.G.P.C. Explor. Conf., Cairo. Preprint.

Gawthorpe RL, Hurst JM, Sladen CP (1990) Evolution of Miocene footwall derived coarsegrained deltas. Gulf of Suez, Egypt: implications for exploration. Bulletin of the American Association of Petroleum Geologists, v. 74, p. 1077-1086 
Gawthorpe RL, Sharp I, Underhill JR, Gupta S (1997) Linked sequence stratigraphic and structural evolution of propagating normal faults. Geology, 25, 795-798

Gawthorpe RL and Leeder MR (2000) Tectono-sedimentary evolution of active extensional basins. Basin Research, v. 12, p. 195-218

Gawthorpe RL, Jackson CAL, Young MJ, Sharp IR, Moustafa AR (2003) Fault growth, interaction, linkage and death: evolution of the Hammam Faraun fault block, Suez rift, Egypt. Journal of Structural Geology, 25, 883-895.

Ghorab MA (1964) Oligocene and Miocene rock stratigraphy of the Gulf of Suez region, unpublished report consultatus stratigraphic committee of the EGPC., Cairo, E.R., 275pp

Gradstein FM, Ogg JG, Schmitz MD, Ogg GM (2012) The Geologic Time Scale. Elsevier doi:10.1016/B978-0-444-59425-9.10003-4

Griffin DL (1999) The late Miocene climate of north-eastern Africa: unravelling the signals in the sedimentary succession: Journal of the Geological Society, v. 156, p. 817-826

Griffin DL (2002) Aridity and humidity: two aspects of the late Miocene climate of North Africa and the Mediterranean. Palaeogeography, Palaeoclimatology, Palaeoecology 182, 6591

Guillocheau F, Rouby D, Robin C, Helm C, Rolland N, Le Carlier de Veslud C, Braun J (2012) Quantification and causes of the terrigeneous sediment budget at the scale of a continental margin: a new method applied to the Namibia-South Africa margin. Basin Research, 24: 3-30. doi: 10.1111/j.1365-2117.2011.00511.x

Gupta S, Cowie PA, Dawers NH, Underhill JR (1998) A. mechanism to explain rift basin subsidence and stratigraphic patterns through fault array evolution. Geology, 26, 595-598

Gupta S, Underhill JR, Sharp IR, Gawthorpe RL (1999) Role of fault interactions in controlling synrift sediment dispersal patterns: Miocene Abu Alaqa Group. Suez Rift, Sinai, Egypt. Basin Research, v. 11. p. 167-189

Gvirtzman Z and Steinberg J (2012) Inland jump of the Arabian northwest plate boundary from the Levant continental margin to the Dead Sea Transform. Tectonics 31, TC4003

Hagras M and Slocki S (1982) Sand distribution of Miocene clastics in the Gulf of Suez. In: HANTAR, G. (ed.) Egyptian General Petroleum Company 6th Exploration Seminar Preprint

Halim M, Said M, EI Azhary T (1996) 13th Petroleum Conference, Vol. I: Exploration, 401420, Oct. 1996, Cairo.

Hagras M (1986) Some geological observations in the Gulf of Suez. 8th Petrol. Explor. Seminar, E.G.P.C., Cairo, 1-12.

Haines SS, Klemperer SL, Brown L, Jingru G, Mechie J, Meissner R, Ross A, Wenjin Z (2003) INDEPTH III seismic data: From surface observations to deep crustal processes in Tibet, Tectonics, 22, 1001, doi:10.1029/2001TC001305, 1 
Helmy M and Zakaria A (1986) El Morgan area geologic framework. Proc. 8th Petrol. Explor. Seminar, E.G.P.C., Cairo

Hughes GW, Abdine S, Girgis MH (1992) Miocene biofacies development and geological history of the Gulf of Suez, Egypt. Mar Pet Geol 9:27

Jackson CAL, Gawthorpe RL, Sharp IR (2002) Growth and linkage of the East Tanka fault zone, Suez rift: structural style and syn-rift stratigraphic response. Journal of Geological Society, London, 159, 175-187

Jackson CAL, Gawthorpe RL, Carr ID, Sharp IR (2005) Normal faulting as a control on the stratigraphic development of shallow marine syn-rift sequences: the Nukhul and Lower Rudeis Formations, Hammam Faraun fault block, Suez Rift, Egypt. Sedimentology, v. 52. p. 313-338

Japsen P, Chambers JA, Green PF, Bonow JM (2011) Elevated, passive continental margins: Not rift shoulders, but expressions of episodic, post-rift burial and exhumation: Global and Planetary Change, 2011

Kappelman J, Simons EL, Swisher III CC (1992) New age determinations for the EoceneOligocene boundary sediments in the Fayum Depression, northern Egypt. Journal of Geology 100, 647-668

Khalil SM and McClay KR (2002) Extensional fault-related folding, northwestern Red Sea, Egypt. Journal of Structural Geology, 24, 743-762

Khaled D, Sehim A, Darwish M (2002) Rift architecture and growth sedimentation across a main accommodation zone, Northern Gulf of Suez - Egypt. Inter. Petroleum Conference and Exhibition, AAPG 2002, Cairo, Egypt

Kohn BP and Eyal M (1981) History of uplift of the crystalline basement of Sinai and its relation to opening of the Red Sea as revealed by fission track dating of apatites, Earth Planet. Sci. Lett. 52, 129-141

Krebs WN, Wescott D, Nummedahl I, Gaafar G, Azazi G, Karamat S (1997) Graphic correlation and sequence stratigraphy of Neogene rocks in the Gulf of Suez. In Fauna, flora and sequence stratigraphy. Association Paleontologie Francaise de Stratigraphie, v. 168, no. 1, p. 64-71

Lague D, Crave A, Davy P (2003) Laboratory experiments simulating the geomorphic response to tectonic uplift. J. Geophys. Res. 108, B1

Lambiase JJ and Bosworth W (1995) Structural controls on sedimentation in continental rifts. In: Lambiase, J.J. (Ed.), Hydrocarbon Habitat in Rift Basins, Geological Society, London, Special Publication 80, 117-144

Leeder MR and Gawthorpe RL (1987) Sedimentary models for extensional tilt-block/halfgraben basins. In M.P. Coward, J.F. Dewey and P.L. Hancock (Eds.), Continental extensional tectonics. Geological Society of London Special Publication No. 28, p. 139-152 
Le Pichon X and Gaulier J-M (1988) The rotation of Arabia and the Levant fault system. Tectonophysics 153, 271-294

Le Quellec P and Colletta B (1985) Synthèse structurale sur le rift du Golfe de Suez. Report C.F.P./I.F.P., I.F.P. report 33724

Leroy S, Razin P, Autin J, Bache F, d'Acremont E, Watremez L, Robinet J, Baurion C, Denèle Y, Bellahsen N, Lucazeau F, Rolandone F, Rouzo S, Serra Kiel J, Robin C et al. (2012) From rifting to oceanic spreading in the Gulf of Aden: a synthesis. Arab J. Geosciences. DOI 10.1007/s12517-011-0475-4, vol 5, 859-901

Lotfy HI, Van der Voo R, Hall CM, Kamel OA, Abdel Aal AY (1995). Palaeomagnetism of Early Miocene basaltic eruptions in the areas east and west of Cairo. Journal of African Earth Sciences 21, 407-419

Lyberis N (1988) Tectonic evolution of the Gulf of Suez and the Gulf of Aqaba.

Tectonophysics, 153, 209-220

McKenzie D (1978) Some remarks on the development of sedimentary basins. Earth and Planet Sci Lett 40:25-32

Macgregor D (2015) History of the development of the East African Rift System: A series of interpreted maps through time. Journal of African Earth Sciences 101 (2015) 232-252

Mann P, Gahagan L, Gordon MB (2003) Tectonic setting of the world's giant oil and gas fields, in M. T. Halbouty, ed., Giant oil and gas fields of the decade 1990-1999, AAPG Memoir 78, p. 15-105

Martin J, Toothill S, Moussavou R (2009) Hunting the pre-salt. Frontier Exploration. Geo Expro Dec. 2006. 39-41

McClay KR, Nichols GJ, Khalil S, Darwish M, Bosworth W (1998) Extensional tectonics and sedimentation, eastern Gulf of Suez. Egypt. In B.H. Purser and D.W.J. Bosence (Eds.), Sedimentation and tectonics of rift basins, Red Sea-Gulf of Aden: Chapman and Hall, London, p. 223-238

Montenat C, Ott d'Estevou P, Purser BH (1986) Tectonic and sedimentary evolution of the Gulf of Suez and the Northwestern Red Sea: a review. Dot. Trav. I.G.A.L., Paris, 10: 7-18

Montenat C, Ott d'Estevou P, Purser B, Burollet PF, Jarrige J-J. Orszag-Sperber F, Philobbos E. Plaziat JC, Prat P, Richert J-P, Roussel N, Thiriet J-P (1988) Tectonic and sedimentary evolution of the Gulf of Suez and the Northwestern Red Sea. Tectonophysics, v. 153, p. 161177

Moretti I and Froidevaux C (1986) Thermomechanical models of active rifting. Tectonics, 3, 501-511

Moretti I (1987) Modélisation de l'extension intracontinentale : exemple du golfe de suez. I.F.P. report 34961 
Moretti I and Chenet PY (1987) The evolution of the Suez rift: a combination of stretching and secondary convection: Tectonophysics, v. 133, p. 229-234

Moretti I and Colletta B (1987) Spatial and temporal evolution of the Suez Rift subsidence. J. Geodyn. 7, 151-168

Moretti I and Pinet B (1987) Discrepancy between lower and upper crustal thinning. In Sedimentary basins and basin-forming mechanisms. Canadian Society of PG, Memoir 12, 233-239

Moussa HE (1987) Geologic studies and genetic correlation of basaltic rocks in west central Sinai. PhD thesis, Ain Shams University, Cairo, Egypt

Moustafa AG (1976) Block faulting in the Gulf of Suez. Proceedings of the 5th Petroleum Exploration and Production Seminar, Egypt, v. 1, 19p.

Moustafa AR (1993) Structural characteristics and tectonic evolution of the east-margin blocks of the Suez rift. Tectonophysics 223, 381-399

Moustafa AR (1996) Internal structure and deformation of an accommodation zone in the northern part of the Suez rift. Journal of Structural Geology, 18, 93-107

Omar GI, Steckler MS, Buck WR, Kohn BP (1989) Fission-track analysis of basement apatites at the western margin of the Gulf of Suez rift, Egypt: evidence for synchronicity of uplift and subsidence. Earth Planet. Sci. Lett. 94, 316-328

Omran MA and El Sharawy MS (2014) Tectonic evolution of the Southern Gulf of Suez, Egypt: a comparison between depocenter and near peripheral basins. Arab J Geosci (2014) 7:87-107. DOI 10.1007/s12517-012-0732-1

O'Reilly C, Chisari D, Clarke J, Musa S, Halliday J, Deighton I, Tobocha E, Chandler P (2015) Comparing the Brazilian and Angolan Conjugate Margin. GeoExpro Oct. 2015. 61-62

Orszag-Sperber F, Harwood G, Kendall A, Purser BH (1998) A review of the evaporites of the Red Sea-Gulf of Suez rift. In, B.H. Purser and D.W.J. Bosence (Eds.), Sedimentation and Tectonics in Rift Basins: Red Sea-Gulf of Aden. Chapman and Hall, London, p. 409-426

Patton TL, Moustafa AR, Nelson RA, Abdine SA (1994) Tectonic evolution and structural setting of the Suez Rift. In S.M. London (Ed.), Interior rift basins. American Association of Petroleum Geologists Memoir No. 59, p. 7-55

Peijs JAMM, Bevan TG, Piombino JT (2012) The Gulf of Suez rift basin. In D.G. Roberts (Ed.), Regional Geology and Tectonics: Phanerozoic Rift Systems and Sedimentary Basins. p. 164-194. doi:10.1016/B978-0-444-56356-9.00007-9

Piron E (2000) Géométrie des failles normales dans le golfe de Suez (Sinaï, Égypte). Aspect 2D en coupe verticale. I.F.P. report 54139 
Plaziat JC, Montenat C, Barrier P, Janin MC, Orszag-Sperber F, Philobbos E (1998)

Stratigraphy of the Egyptian syn-rift deposits: correlations between axial and peripheral sequences of the north-western Red Sea and Gulf of Suez and their relations with tectonics and eustacy. In, B.H. Purser and D.W.J. Bosence (Eds.), Sedimentation and Tectonics in Rift Basins: Red Sea-Gulf of Aden. Chapman and Hall, London, p. 211-222

Poag CW and Sevon WD (1989) A record of Appalachian denudation in Post-Rift Mesozoic and Cenozoic sedimentary deposits of the U.S. Middle Atlantic Continental margin. Geomorphology, 2, 119-157

Prosser S (1993) Rift-related linked depositional systems and their seismic expression. In: Williams, G.D. \& Dobb, A. (eds) Tectonics and Seismic Sequence Stratigraphy. Geological Society, London, Special Publications, 71, 35-66

Purser BH and Hötzl H (1988) The sedimentary evolution of the Red Sea rift: a comparison of the northwest (Egyptian) and northeast (Saudi Arabian) margins. Tectonophysics 153:193208

Richardson M and Arthur MA (1988) The Gulf of Suez-northern Red Sea Neogene rift: a quantitative basin analysis. Marine Pet. Geol. 5, 247-270

Rohais S, Eschard R, Ford M, Guillocheau F, Moretti I (2007a) Stratigraphic architecture of the Plio-Pleistocene Infill of the Corinth rift: implications for its structural evolution. Tectonophysics 440, 5-28

Rohais S, Colletta B, Moretti I (2007b) The Gulf of Suez: Regional setting, petroleum system and tectonic-sedimentation relationship. Field guide, Nov. 2007. Unpublished IFPEN report

Rohais S, Bonnet S, Eschard R (2012) Sedimentary record of tectonic and climatic erosional perturbations in an experimental coupled catchment-fan system. Basin Research, 24: 198212. doi: $10.1111 /$ j.1365-2117.2011.00520.x

Rohais S, Barrois A, Colletta B, Moretti I (2013) Architecture stratigraphique et évolution paléogéographique du Golfe de Suez : Apports de l'enregistrement sédimentaire sur la dynamique d'un rift. 14ème congrès français de sédimentologie. 5-7 novembre 2013, Paris : Centre des congrès de la Villette

Rohais S, Barrois A, Colletta B, Moretti I (2015) Presalt to Salt Paleogeography and Stratigraphic Architecture in a Rift Basin: Insights From a Basin-Scale Study of the Gulf of Suez (Egypt). AAPG Datapages/Search and Discovery Article \#90217 @ 2015 International Conference \& Exhibition, Melbourne, Australia, September 13-16, 2015

Rouby D, Bonnet S, Guillocheau F, Gallagher K, Robin C, Biancotto F, Dauteuil O, Braun J (2009) Sediment supply to the Orange sedimentary system over the last150 My: an evaluation from sedimentation/denudation balance. Mar. Petrol. Geol., 26, 782-794

Rouchy JM, Nod D, Wali AMA, Aref MAM (1995) Evaporitic and biosiliceous cyclic sedimentation in the Miocene of the Gulf of Suez-depositional and diagenetic aspects. Sediment Geol 94:277-297 
Salah MG and Alsharhan AS (1997) The Miocene Kareem Formation in the southern Gulf of Suez, Egypt: a review on stratigraphy and petroleum geology. Journal of Petroleum Geology, v. 20 , no. 3 , p. $327-346$

Sarhan MA, Richard Ell, Collier RELl, Basal A, Abdel Aal MH (2014) Late Miocene normal faulting beneath the northern Nile. Delta: NNW propagation of the Gulf of Suez Rift. Arab J Geosci (2014) 7:4563-4571. DOI 10.1007/s12517-013-1089-9

Saoudi A and Kalil B (1984) Distribution and hydrocarbon potential of Nukhul sediments in the Gulf of Suez. In Egyptian General Petroleum Corporation. 7th EGPC Exploration Seminar, Cairo, Egypt, 75-96

Schütz KI (1994) Structure and stratigraphy of the Gulf of Suez, Egypt. In S. M. Landon (Ed.), Interior rift basins. American Association of Petroleum Geologists Memoir No. 59, p. $57-96$

Scott RW and Govean FM (1985) Early depositional history of a rift basin: Miocene in western Sinai. Palaeogeogr. Palaeoclimatol. Palaeoecol. 62, 143-158

Sellwood BW and Netherwood RE (1984) Facies evolution in the Gulf of Suez area: sedimentation history as an indicator of rift initiation and development Modern Geol. 9, 43-69

Sleep N, Nunn J, Chou L (1980) Platform basins, annual Reviews of Earth and Planetary Science, V 8, 17-34

Smale JLR, Thunell C, Schamel S (1988) Sedimentologic evidence for early Miocene fault reactivation in the Gulf of Suez: Geology, v. 16, p. 113-116

Steckler MS (1985) Uplift and extension at the Gulf of Suez: indications of induced mantle convection. Nature 317, 135-139

Steckler MS, Bertholot F, Lyberis N, Le Pichon X (1988) Subsidence in the Gulf of Suez: implications for rifting and plate kinematics. Tectonophysics 153, 249-270

Thiriet JP (1987) Evolution tectonique et sédimentaire de la marge occidentale de la Mer Rouge au Néogène de Port Safaga (Egypte), PhD, 1333pp., Univ. Claude-Bernard, Lyon, France

van der Beek P, Cloetingh S, Andriessen P (1994) Mechanisms of extensional basin formation and vertical motions at rift flanks: constraints from tectonic modeling and fission-track thermochronology. Earth Planet. Sci. Lett. 121, 417-433

Warren JK (2010) Evaporites through time: Tectonic, climatic and eustatic controls in marine and nonmarine deposits: Earth-Science Reviews, v. 98/3-4, p. 217-268

Wernicke B (1985) Uniform-sense normal simple shear of the continental lithosphere. Canadian Journal of Earth Sciences, 1985, 22:108-125, 10.1139/e85-009

Wescott WA, Krebs WN, Sikora PJ, Boucher PJ, Stein SA (1998) Modern applications of biostratigraphy in exploration and production. The Leading Edge. Oct. 1998, 1204-1210 
Winn RD, Crevello PD, Bosworth W (2001) Lower Miocene Nukhul Formation, Gebel el Zeit, Egypt: Model for structural control on early synrift strata and reservoirs, Gulf of Suez. Bulletin of the American Association of Petroleum Geologists, v. 85, no. 10, p. 1871-1890

Young MJ, Gawthorpe RL, Sharp IR (2000) Sedimentology and sequence stratigraphy of a transfer zone coarse-grained delta, Miocene Suez Rift, Egypt. Sedimentology, v. 47, p. 10811104

Young MJ, Gawthorpe RL, Sharp IR (2003) Normal fault growth and early syn-rift sedimentology and sequence stratigraphy: Thal Fault, Suez Rift, Egypt. Basin Research, 15, 479-502.

Zierenberg RA and Shanks III WC (1986) Isotopic constraints on the origin of the Atlantis II, Suakin and Valdivia brines, Red Sea, Geochem. Cosmochim. Acta 50, 2205-2214 


\section{FIGURE CAPTION}

Figure 1

A. Structural map of the Suez rift (modified from Colletta et al. 1988; Patton et al. 1994; Bosworth and McClay 2001; Peijs et al. 2012). Hatched areas indicate major accommodation zones. Red lines correspond to the two cross sections presented in Figure 3. B. Geodynamic setting of the Gulf of Suez (modified from Bosworth et al. 2005). Major elements of the Aqaba-Levant intra-continental transform boundary, the Bitlis-Zagros convergence zone and the Red Sea - Gulf of Aden are highlighted. The red rectangle shows the Gulf of Suez that corresponds to the NW termination of the Red Sea. C. Simplified stratigraphic column of the Suez rift (modified from EGPC 1964; Richardson and Arthur 1988; Patton et al. 1994; Bosworth and McClay 2001; Abd El-Naby et al. 2010).

Figure 2

Synthetic stratigraphic setting for the syn-rift succession of the Suez rift. Lithologies are derived from different wells to illustrate the typical sedimentary character of each formation. Silty rich for restricted deposits in green versus mud rich for offshore deposits in light blue. The association zones, main environment of deposition (EOD) and dominant paleoenvironmental conditions are modified from Hughes et al. (1992). Sequences are modified from Wescott et al. (1998) and Krebs et al. (1997). Colour code for system tracts: blue $=$ transgressive, red $=$ highstand and falling stage, orange $=$ lowstand .

\section{Figure 3}

(A) and (B) N-S cross sections flattened on the top Zeit marker (locally base Pliocene when top Zeit Fm is not preserved) showing the distribution of the main depositional units (A) and the dominant lithologies (B) within each sub-basins and across the two accommodation zones. (C) and (D) E-W cross section flattened on the top Zeit marker (locally base Pliocene when top Zeit Fm is not preserved) showing the distribution of the main depositional units (C) and the dominant lithologies (D) within the Central Basin. Sections cross-cut at well 13.

Figure 4

Maps with dominant lithologies for the Nukhul Fm (a-c, ca. Aquitanian), Rudeis Fm (d-g, ca. Burdigalian), Kareem Fm (h-k, ca. Langhian), Belayim Fm (l-o, ca. Serravallian), South Gharib Fm (p-q, ca. Tortonian) and Zeit Fm (r-s, ca. Messinian). Time intervals are approximated using association zones from Hughes et al. (1992). Shales are subdivided into silty rich for restricted deposits in green versus mud rich for offshore deposits in light blue. Paleobathymetries are estimated using the results of Hughes et al. (1992). Only the deepest parts are highlighted to keep the maps readable. See Figure 1 for further information about the keys.

\section{Figure 5}

Main depocenters and distribution of the syn-rift deposits for the main stratigraphic units of the Suez rift. a. Oligocene - Chattian. b. Nukhul Fm, cut-off to highlight depocenters at 300 m. c. Rudeis Fm, cut-off to highlight depocenters at 1000 m. d. Kareem Fm, cut-off to highlight depocenters at $400 \mathrm{~m}$. e. Belayim Fm, cut-off to highlight depocenters at $200 \mathrm{~m}$. f. South Gharib Fm, cut-off to highlight depocenters at $900 \mathrm{~m}$. g. Zeit Fm, cut-off to highlight depocenters at $600 \mathrm{~m}$. See Figure 1 for further information about the keys.

Figure 6 
Synthesis for the pre-salt and salt deposits of the Suez rift of evaporite and carbonate accumulation rate $\left(\mathrm{km}^{3} / \mathrm{Myr}\right)$, mean sediment supply $\left(\mathrm{km}^{3} / \mathrm{Myr}\right)$ and cumulative tectonic subsidence curves (modified from the wells analysed by Moretti and Colletta 1987;

Richardson and Arthur 1988). The grey area includes all the wells analysed for estimating the cumulative tectonic subsidence. The chronostratigraphy, microfossil biozones and sea-level curve are derived from Gradstein et al. (2012). Relative proportions of lithology for each map have been combined with thickness map to estimate the accumulation rate and sediment supply. See text for further information.

\section{TABLE CAPTION}

Table 1

Results of the mass balance characterization of the pre-salt to salt syn-rift deposits of the Suez rift. The preferred scenario is highlighted in grey. See text for further explanation. 
Figure1 $\mathrm{A}$ Keys

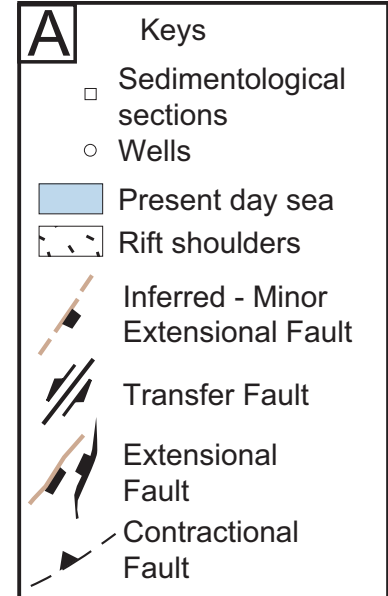

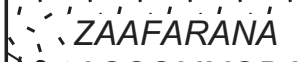

'S'ACCOMMODATIONA

$\because \because Z O N E$ ZWA $\because \because \cdots$

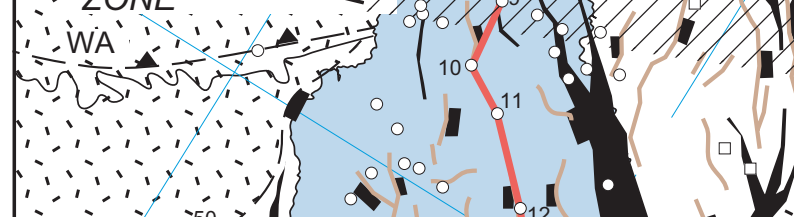

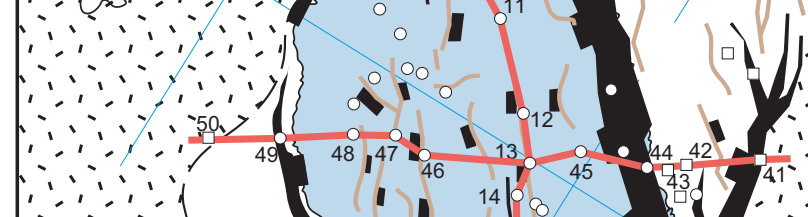
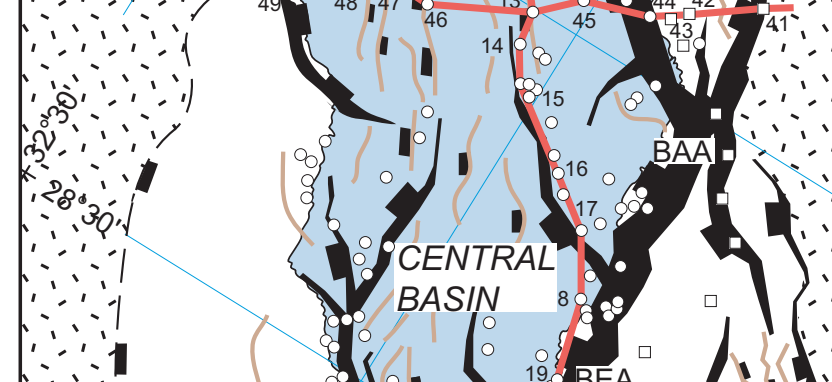

$\because \because$
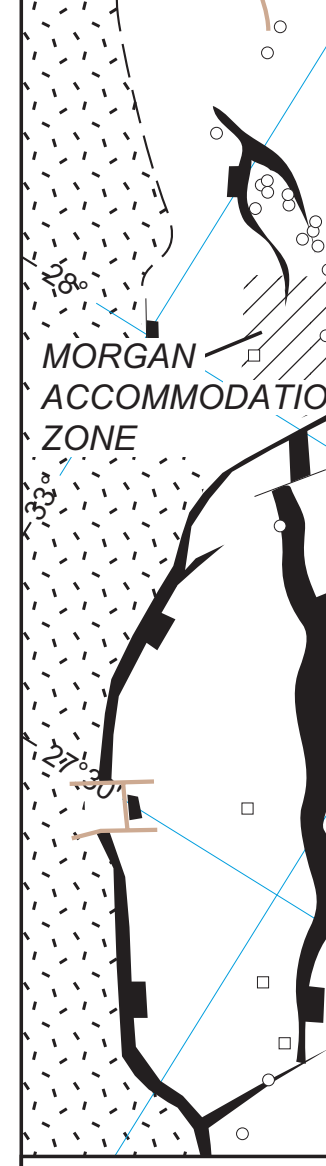

WA: Wadi Araba

BAA: Baba area

BEA: Belayim area

EQP: El Qaa Plain

GZA: Gebel Zeit area

Suez

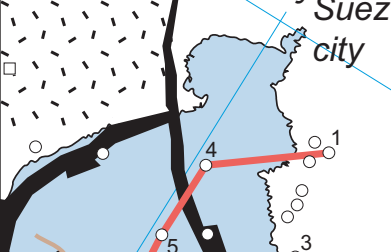

4

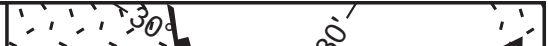

$B 0^{\circ}$

$60^{\circ}$

Ni:

$\therefore 1$
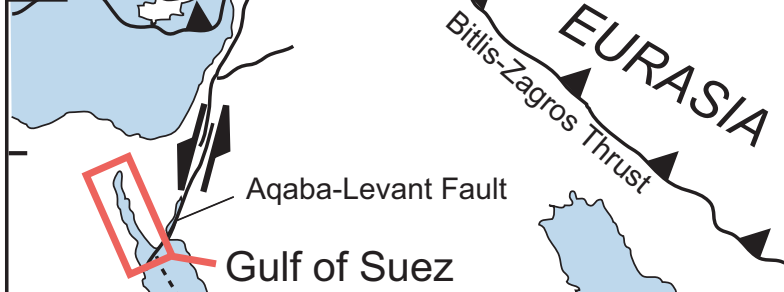

$30^{\circ} \mathrm{N}$
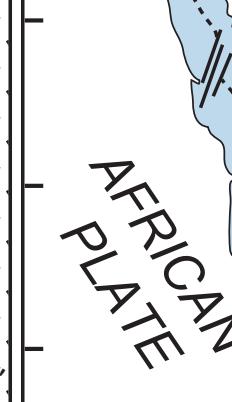

(1/,

ARABIAN

PLATE

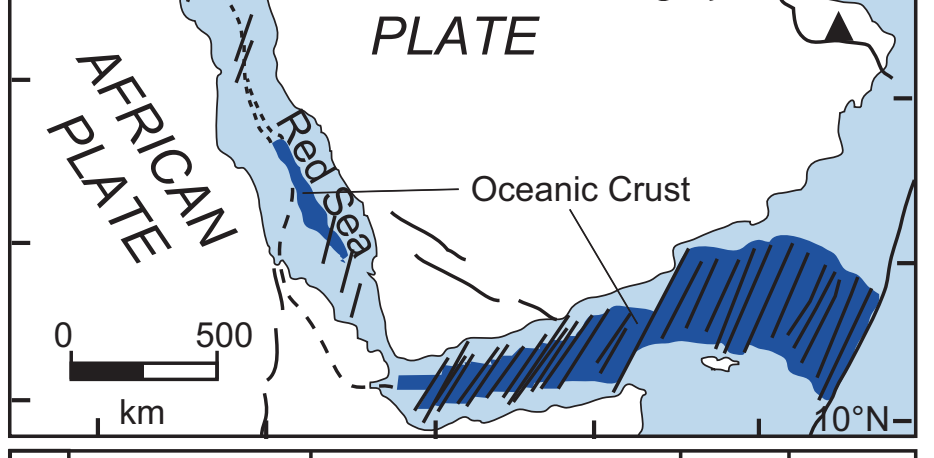

\section{$\mathrm{C}$}

\begin{tabular}{|l|l|l|l|l|}
\hline C Stratigraphy & Groups and Formations & Litho. & $\begin{array}{c}\text { Rifting } \\
\text { Phases }\end{array}$ \\
\hline
\end{tabular}

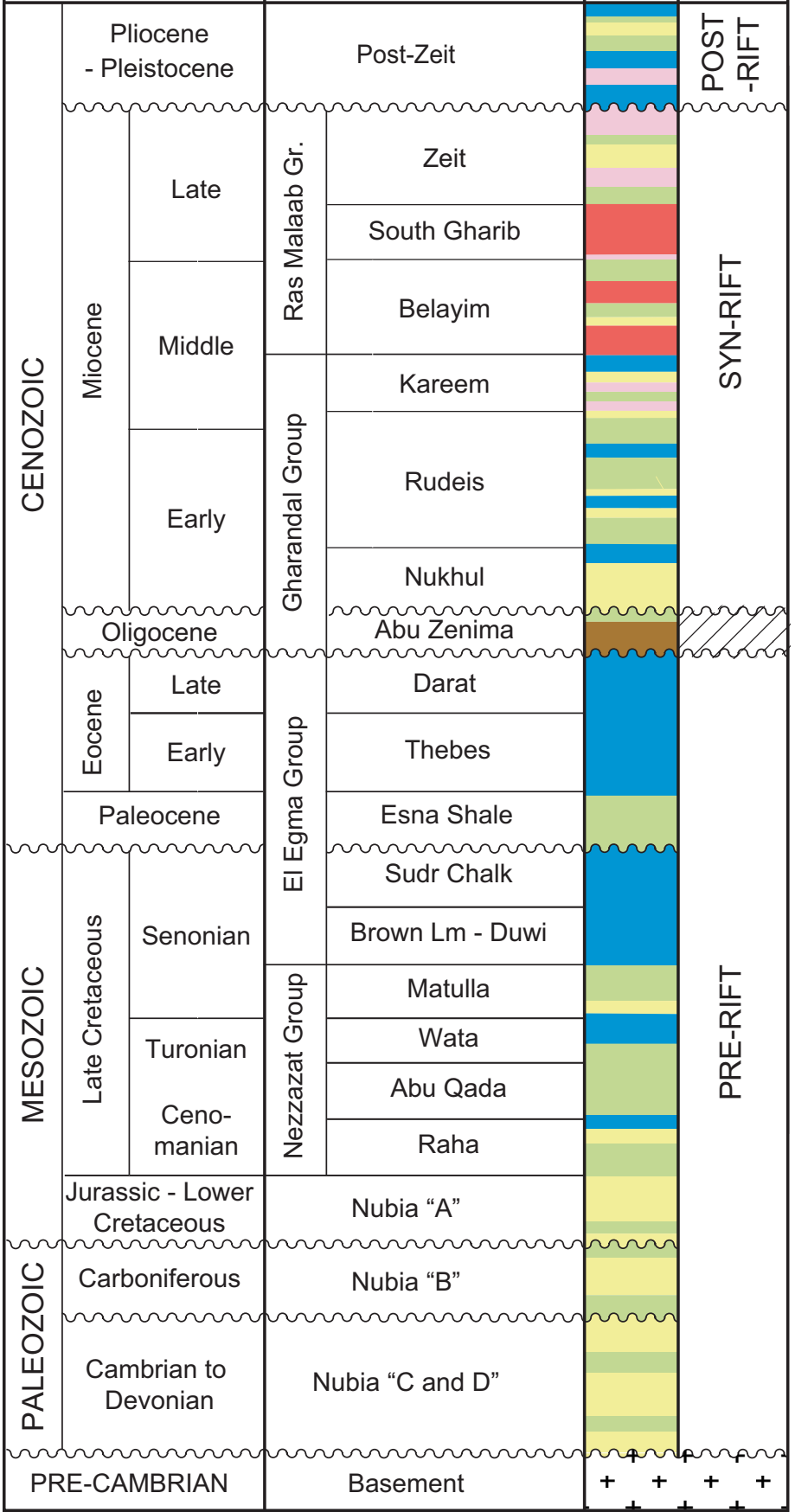




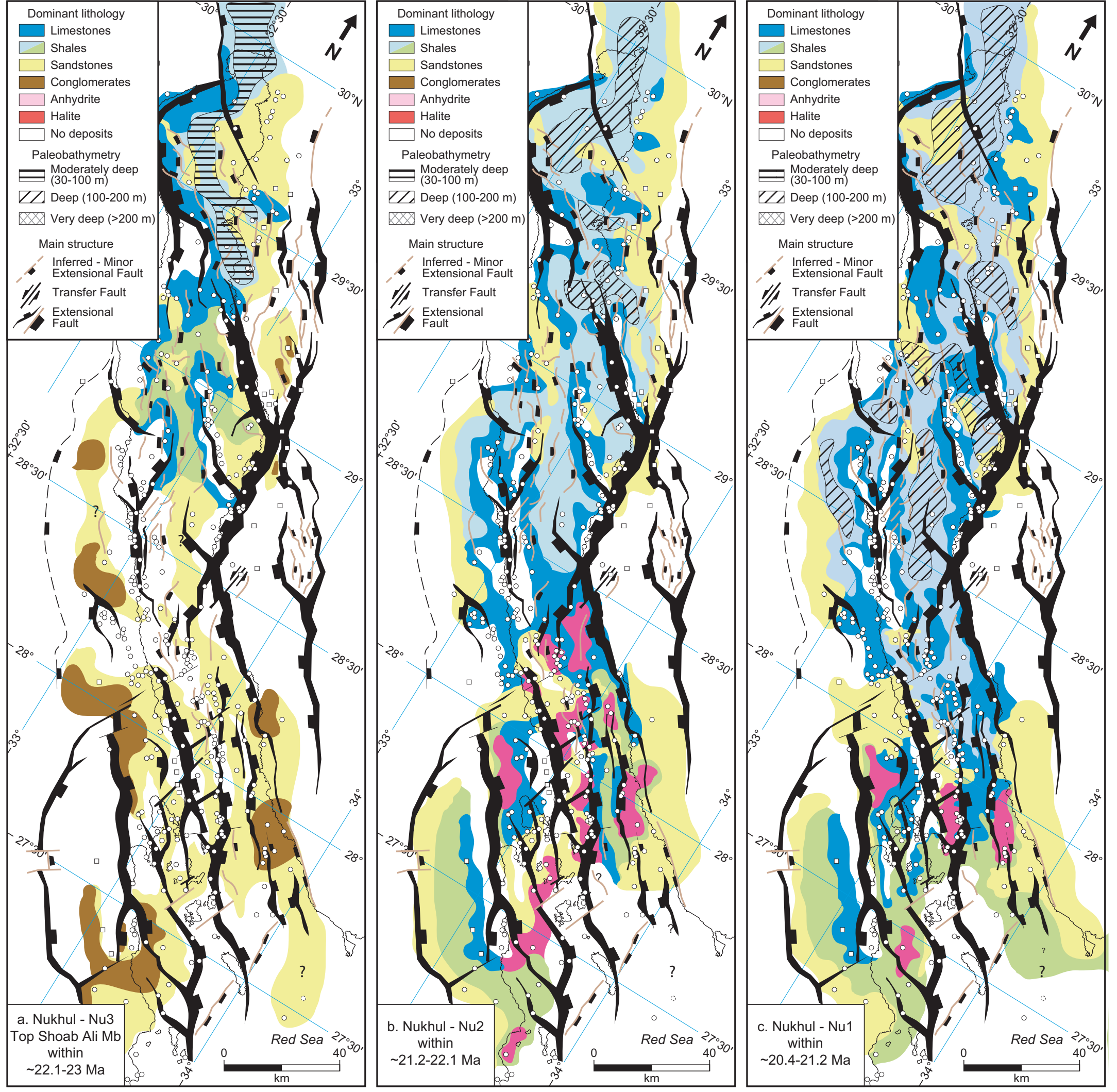




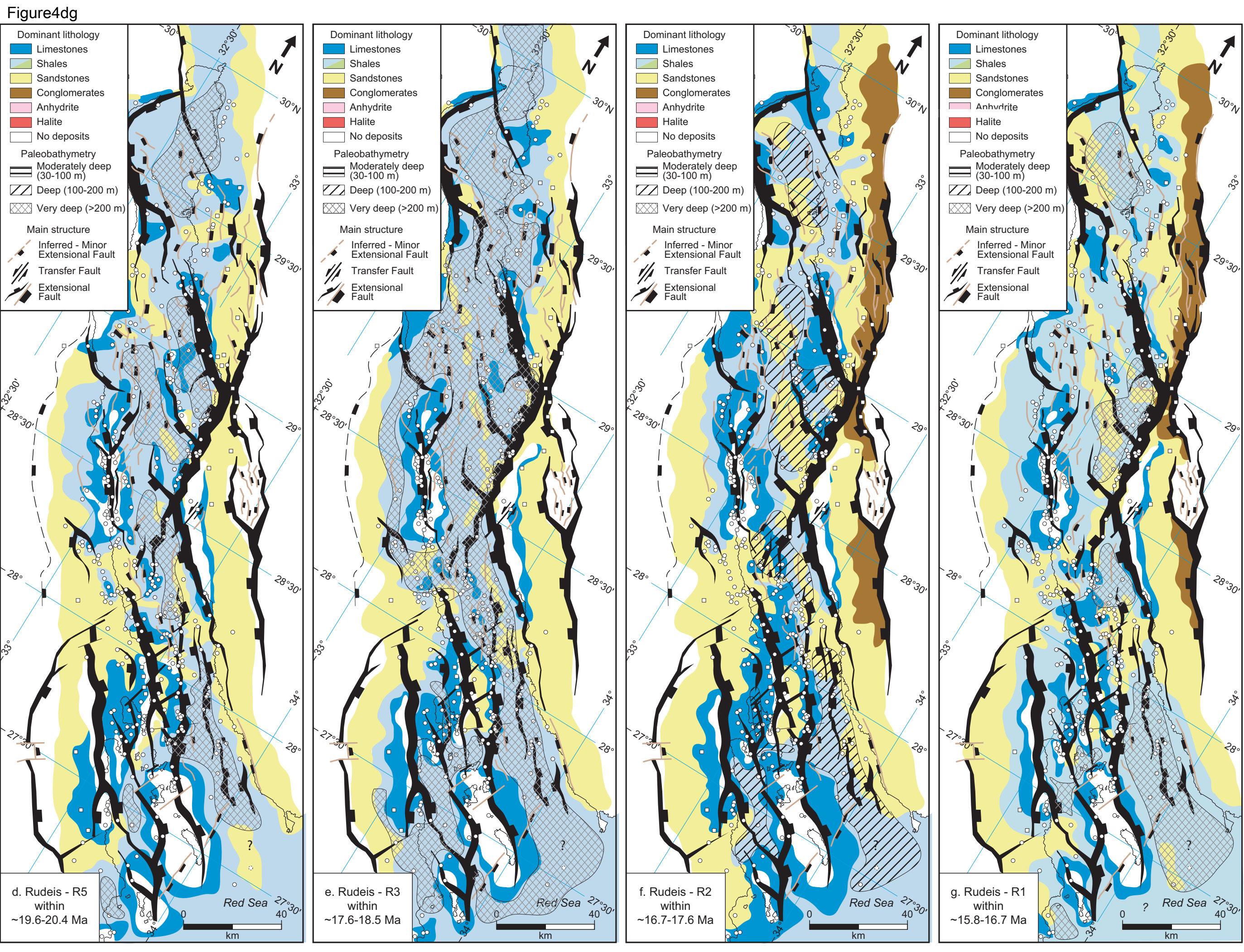




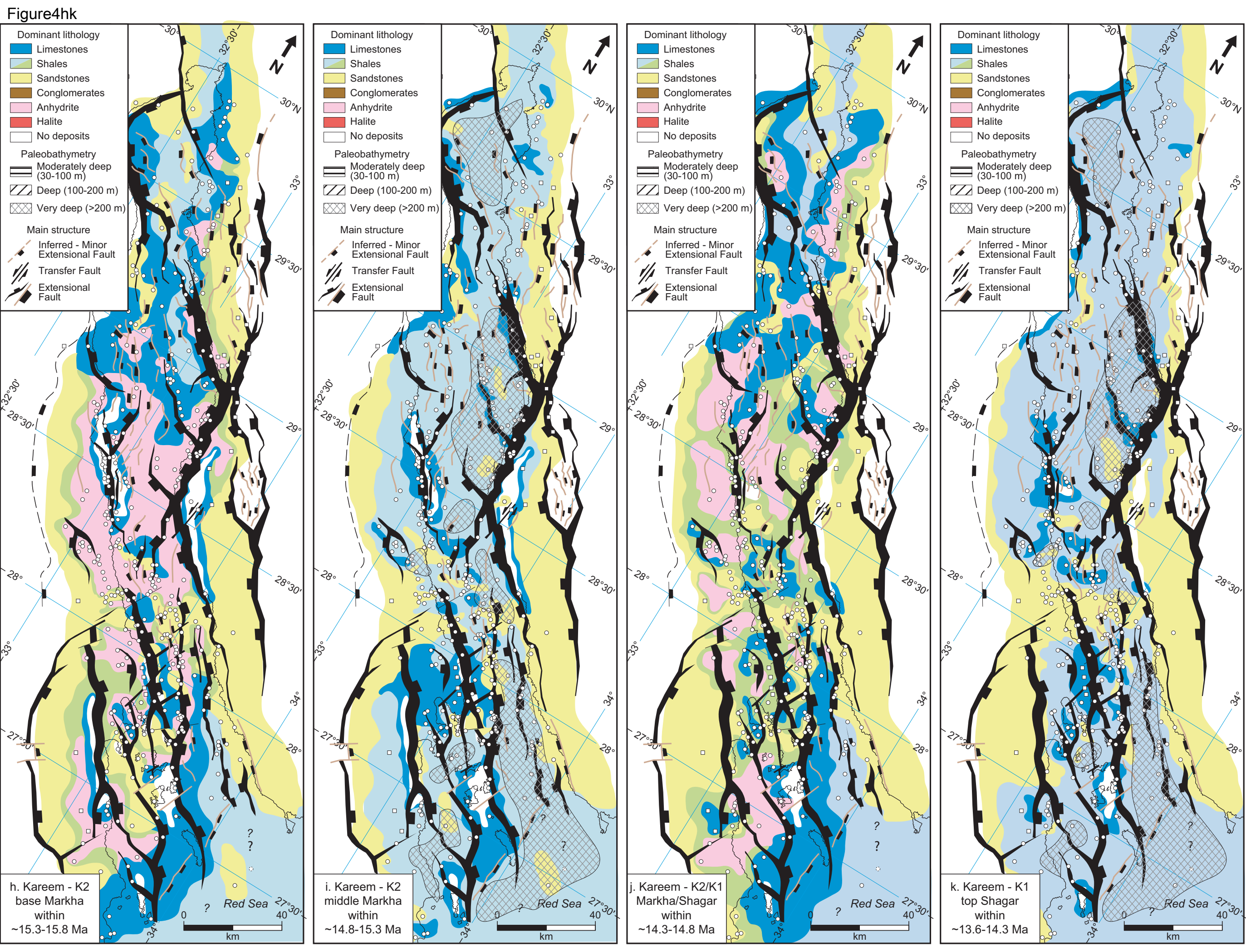




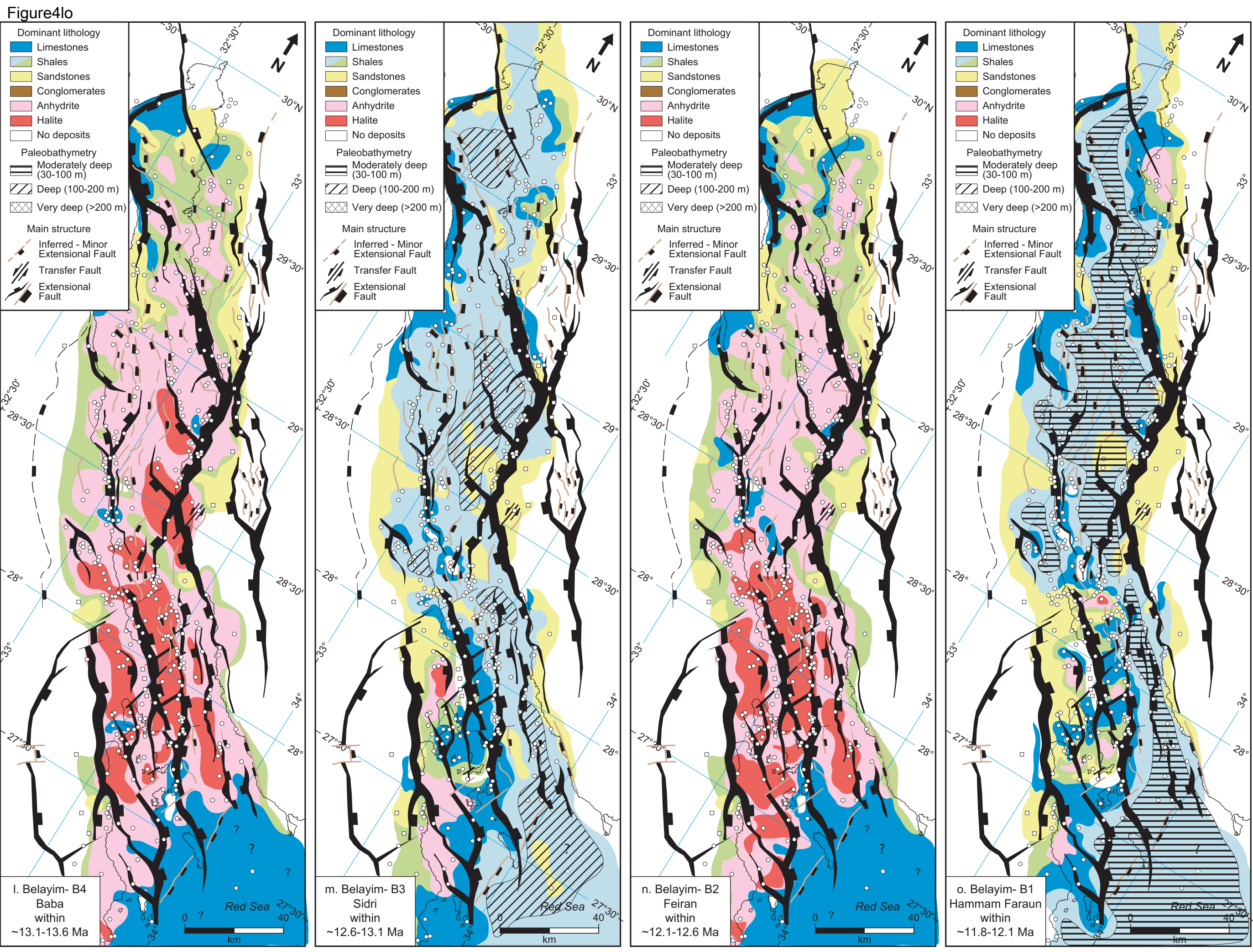




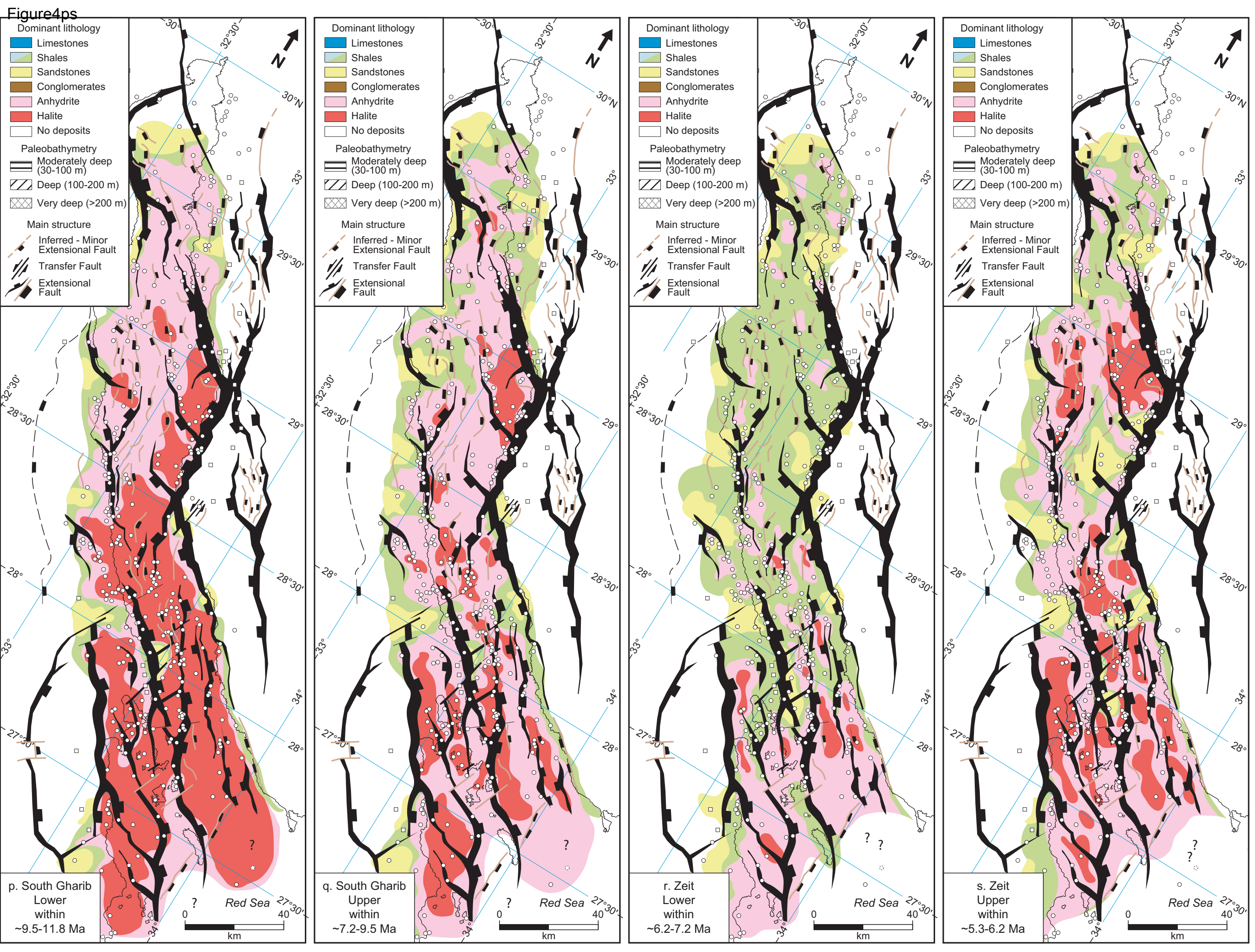




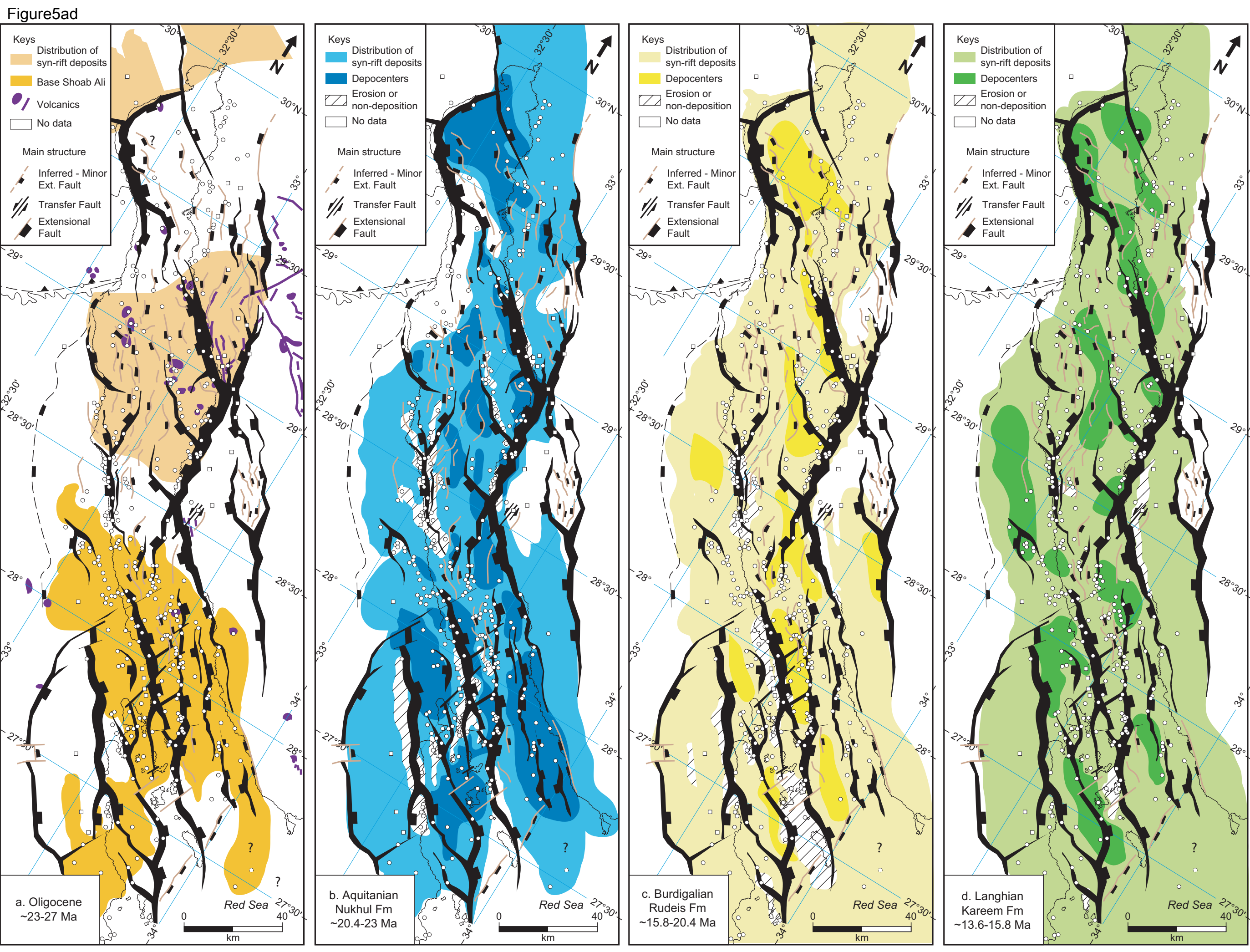




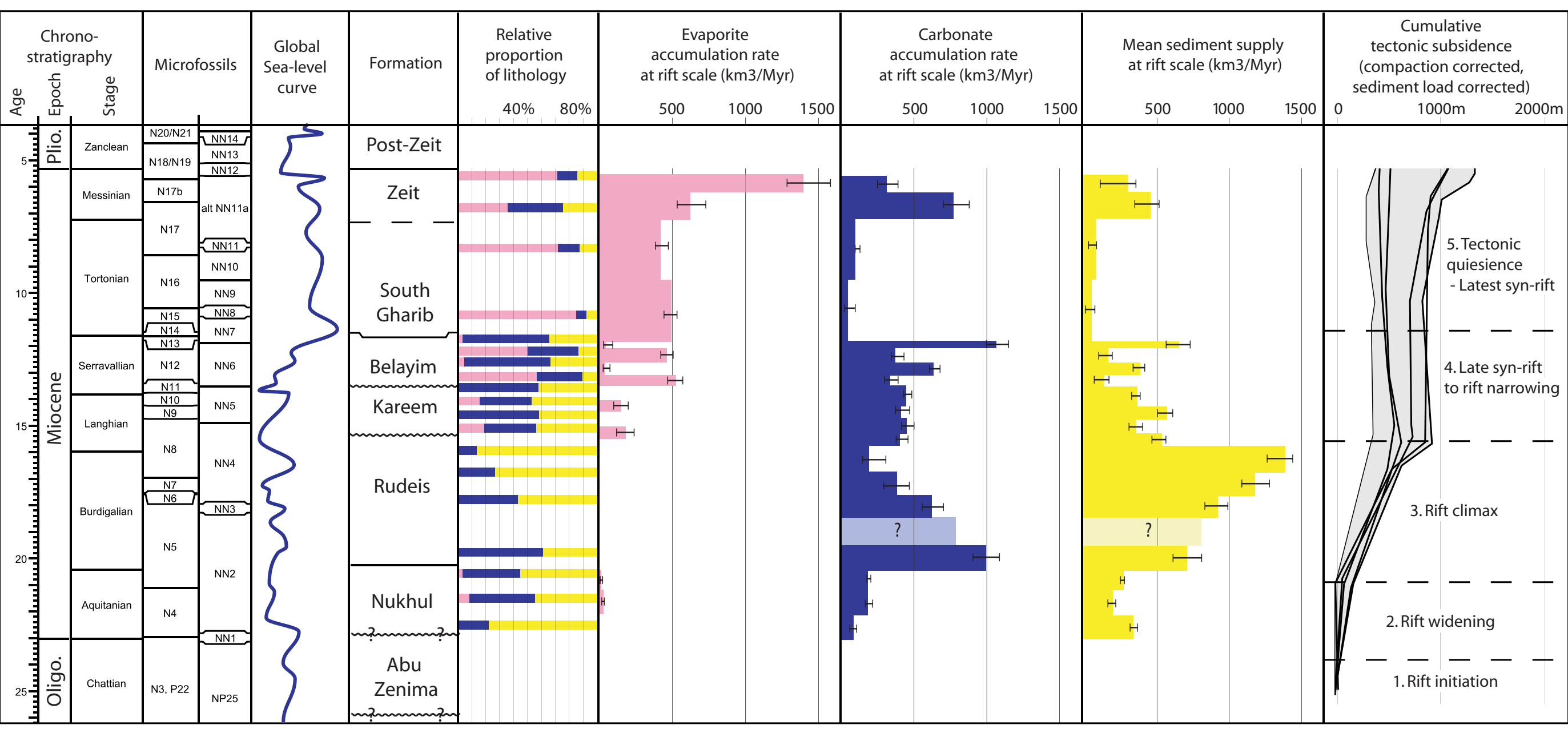




\begin{tabular}{|c|c|c|c|c|c|c|c|c|c|c|c|c|c|c|c|c|c|c|c|c|c|c|c|c|}
\hline \multirow[t]{3}{*}{ Formation } & \multirow[t]{3}{*}{ Map } & \multirow[t]{3}{*}{ Figure } & \multicolumn{2}{|c|}{ Estimated duration (Myr) } & \multicolumn{2}{|c|}{$\begin{array}{l}\text { Preserved } \\
\text { Volume at rift } \\
\text { scale }\end{array}$} & \multicolumn{9}{|c|}{ Relative proportion } & \multirow{2}{*}{\multicolumn{3}{|c|}{$\begin{array}{l}\text { Evaporite accummulation rate } \\
(\mathrm{km} 3 / \mathrm{Myr})\end{array}$}} & \multirow{2}{*}{\multicolumn{3}{|c|}{$\begin{array}{l}\text { Carbonate accummulation } \\
\text { rate }(\mathrm{km} 3 / \mathrm{Myr})\end{array}$}} & \multicolumn{3}{|c|}{$\begin{array}{l}\text { Mean Sediment supply at rift } \\
\text { scale (km3/Myr) }\end{array}$} \\
\hline & & & \multirow[t]{2}{*}{ Age (Ma) } & \multirow[t]{2}{*}{ Duration (Myr) } & \multirow[t]{2}{*}{$\mathrm{Km3}$} & \multirow[t]{2}{*}{$\mathrm{Km3}$} & \multicolumn{3}{|c|}{ Evaporites } & \multicolumn{3}{|c|}{ Carbonates } & \multicolumn{3}{|c|}{ Siliciclastics } & & & & & & & & & \\
\hline & & & & & & & \begin{tabular}{|l} 
Pref. \\
\end{tabular} & Max. & Min. & Pref. & Max. & Min. & Pref. & Max. & Min. & Pref. & Max. & Min. & Pref. & Max. & Min. & Pref. & Max. & Min. \\
\hline \multirow[t]{2}{*}{ Zeit } & Zeit Upper & $4 \mathrm{~s}$ & $5.3-6.2$ & 0.9 & \multirow[t]{2}{*}{3558} & 1779 & 0.71 & 0.8 & 0.65 & 0.15 & 0.18 & 0.11 & 0.15 & 0.18 & 0.11 & 1393.7 & 1581.3 & 1284.8 & 315.3 & 391.4 & 249.9 & 296.4 & 355.8 & 108.7 \\
\hline & Zeit Lower & $4 \mathrm{r}$ & $6.2-7.2$ & 1 & & 1779 & 0.35 & 0.41 & 0.30 & 0.39 & 0.45 & 0.36 & 0.25 & 0.29 & 0.20 & 624.0 & 729.4 & 533.7 & 772.6 & 880.6 & 703.0 & 452.6 & 515.9 & 347.2 \\
\hline \multirow[t]{2}{*}{$\begin{array}{l}\text { South } \\
\text { Gharib }\end{array}$} & $\begin{array}{l}\text { South Gharib } \\
\text { Upper }\end{array}$ & $4 q$ & $7.2-9.5$ & 2.3 & \multirow[t]{2}{*}{2723} & 1361 & 0.71 & 0.8 & 0.65 & 0.15 & 0.2 & 0.15 & 0.13 & 0.14 & 0.09 & 421.4 & 473.5 & 384.7 & 99.8 & 130.2 & 96.5 & 79.8 & 82.9 & 27.6 \\
\hline & $\begin{array}{l}\text { South Gharib } \\
\text { Lower }\end{array}$ & $4 p$ & $9.5-11.8$ & 2.3 & & 1361 & 0.84 & 0.9 & 0.75 & 0.07 & 0.15 & 0.04 & 0.09 & 0.12 & 0.01 & 497.6 & 532.7 & 443.9 & 47.0 & 97.7 & 25.6 & 51.5 & 71.0 & 5.5 \\
\hline \multirow[t]{4}{*}{ Belayim } & \begin{tabular}{|l|} 
Belayim-B1 \\
Hammam Faraun \\
\end{tabular} & 40 & $11.8-12.1$ & 0.3 & \multirow[t]{4}{*}{1874} & 469 & 0.03 & 0.06 & 0.02 & 0.62 & 0.67 & 0.58 & 0.35 & 0.39 & 0.30 & 44.7 & 93.7 & 31.2 & 1066.1 & 1151.0 & 998.7 & 657.4 & 730.9 & 564.8 \\
\hline & Belayim-B2 Feiran & $4 n$ & $12.1-12.6$ & 0.5 & & 469 & 0.49 & 0.54 & 0.45 & 0.36 & 0.42 & 0.34 & 0.14 & 0.17 & 0.09 & 462.3 & 506.0 & 421.7 & 374.3 & 432.9 & 347.0 & 161.5 & 191.2 & 97.5 \\
\hline & Belayim-B3 Sidri & $4 m$ & $12.6-13.1$ & 0.5 & & 469 & 0.04 & 0.08 & 0.03 & 0.62 & 0.66 & 0.59 & 0.34 & 0.37 & 0.30 & 38.5 & 75.0 & 28.1 & 634.3 & 680.3 & 607.0 & 386.2 & 416.1 & 336.1 \\
\hline & Belayim-B4 Baba & 41 & $13.1-13.6$ & 0.5 & & 469 & 0.56 & 0.61 & 0.50 & 0.32 & 0.38 & 0.29 & 0.12 & 0.15 & 0.06 & 525.4 & 571.6 & 468.5 & 333.6 & 391.7 & 298.2 & 130.1 & 168.7 & 66.7 \\
\hline \multirow[t]{4}{*}{ Kareem } & $\begin{array}{l}\text { Kareem-K1 top } \\
\text { Shagar }\end{array}$ & $4 \mathrm{k}$ & $13.6-14.3$ & 0.7 & \multirow[t]{4}{*}{1994} & 498 & & & & 0.57 & 0.62 & 0.55 & 0.43 & 0.45 & 0.38 & & & & 447.8 & 485.6 & 430.8 & 366.0 & 384.5 & 324.7 \\
\hline & $\begin{array}{l}\text { Kareem-K2/K1 } \\
\text { Markha/Shagar }\end{array}$ & $4 j$ & $14.3-14.8$ & 0.5 & & 498 & 0.15 & 0.2 & 0.10 & 0.37 & 0.43 & 0.34 & 0.48 & 0.51 & 0.42 & 148.3 & 199.4 & 99.7 & 410.2 & 471.5 & 374.2 & 570.8 & 610.1 & 503.9 \\
\hline & \begin{tabular}{|l|} 
Kareem-K2 middle \\
Markha
\end{tabular} & $4 \mathrm{i}$ & $14.8-15.3$ & 0.7 & & 498 & & & & 0.58 & 0.64 & 0.53 & 0.42 & 0.47 & 0.36 & & & & 451.6 & 501.3 & 415.1 & 361.9 & 401.6 & 307.6 \\
\hline & \begin{tabular}{|l|} 
Kareem-K2 base \\
Markha
\end{tabular} & $4 \mathrm{~h}$ & $15.3-15.8$ & 0.5 & & 498 & 0.18 & 0.24 & 0.12 & 0.37 & 0.42 & 0.35 & 0.44 & 0.47 & 0.40 & 184.2 & 239.3 & 1119.6 & 406.0 & 460.6 & 378.6 & 532.3 & 562.3 & 466.2 \\
\hline \multirow[t]{4}{*}{ Rudeis } & Rudeis-R1 & $4 g$ & $15.8-16.7$ & 0.9 & \multirow[t]{4}{*}{5999} & 1200 & & & & 0.15 & 0.21 & 0.10 & 0.85 & 0.9 & 0.79 & & & & 193.9 & 308.0 & 146.6 & 1388.4 & 1439.8 & 1263.9 \\
\hline & \begin{tabular}{|l|} 
Rudeis-R2 \\
\end{tabular} & $4 f$ & $16.7-17.6$ & 0.9 & & 1200 & & & & 0.26 & 0.32 & 0.20 & 0.74 & 0.8 & 0.68 & & & & 385.0 & 469.3 & \begin{tabular}{|l|}
293.3 \\
\end{tabular} & 1180.0 & 1279.9 & 1087.9 \\
\hline & Rudeis-R3 & $4 e$ & $17.6-18.5$ & 0.9 & & 1200 & & & & 0.43 & 0.48 & 0.38 & 0.57 & 0.62 & 0.52 & & & & 624.1 & 703.9 & 557.3 & 919.2 & 991.9 & 831.9 \\
\hline & \begin{tabular}{|l|} 
Rudeis-R5 \\
\end{tabular} & $4 d$ & $19.6-20.4$ & 0.8 & & 1200 & & & & 0.61 & 0.66 & 0.55 & 0.39 & 0.45 & 0.34 & & & & 998.3 & 1088.9 & \begin{tabular}{|l|l|}
907.4 \\
\end{tabular} & 711.0 & 809.9 & 611.9 \\
\hline Nukhul & Nukhul-Nu1 & $4 \mathrm{c}$ & $20.4-21.2$ & 0.8 & 969 & 323 & 0.03 & 0.06 & 0.02 & 0.41 & 0.46 & 0.40 & 0.56 & 0.57 & 0.51 & 11.8 & 24.2 & 8.1 & 183.0 & 204.3 & 178.0 & 270.6 & 276.2 & 247.4 \\
\hline & \begin{tabular}{|l|} 
Nukhul-Nu2 \\
\end{tabular} & $4 \mathrm{~b}$ & $21.2-22.1$ & 0.9 & & 323 & 0.08 & 0.1 & 0.05 & 0.47 & 0.55 & 0.42 & 0.45 & 0.5 & 0.37 & 27.8 & 35.9 & 17.9 & 184.9 & 217.1 & 166.9 & 195.7 & 215.3 & 160.5 \\
\hline & $\begin{array}{l}\text { Nukhul-Nu3 top } \\
\text { Shoab Ali Mb. }\end{array}$ & $4 a$ & $22.1-23$ & 0.9 & & 323 & & & & 0.22 & 0.27 & 0.15 & 0.78 & 0.85 & 0.73 & & & & 85.2 & 106.6 & 59.2 & 337.7 & 366.1 & 314.4 \\
\hline
\end{tabular}

